\title{
University Students' Perceptions of the Relationship between Bus Pass Ownership and Physical Activity Levels
}

Hieu Ly, The University of Western Ontario

Supervisor: Dr. Jennifer D. Irwin, The University of Western Ontario

A thesis submitted in partial fulfillment of the requirements for the Master of Science degree in Health and Rehabilitation Sciences

(C) Hieu Ly 2015

Follow this and additional works at: https://ir.lib.uwo.ca/etd

Part of the Community Health and Preventive Medicine Commons

\section{Recommended Citation}

Ly, Hieu, "University Students' Perceptions of the Relationship between Bus Pass Ownership and Physical Activity Levels" (2015). Electronic Thesis and Dissertation Repository. 2805.

https://ir.lib.uwo.ca/etd/2805

This Dissertation/Thesis is brought to you for free and open access by Scholarship@Western. It has been accepted for inclusion in Electronic Thesis and Dissertation Repository by an authorized administrator of Scholarship@Western. For more information, please contact wlswadmin@uwo.ca. 


\section{UNIVERSITY STUDENTS' PERCEPTIONS OF THE RELATIONSHIP BETWEEN BUS PASS OWNERSHIP AND PHYSICAL ACTIVITY LEVELS}

(Thesis format: Monograph)

by

Hieu Ly

Graduate Program in

Health and Rehabilitation Sciences

A thesis submitted in partial fulfillment

of the requirements for the degree of

Masters of Science

The School of Graduate and Postdoctoral Studies

The University of Western Ontario

London, Ontario, Canada

(C) Hieu Ly 2015 


\begin{abstract}
The purpose of this study was to assess the relationship between university students': (a) perceptions of having a discounted bus pass and transit-related physical activity; (b) perceptions of having a discounted bus pass and weekly physical activity levels; and (c) transit-related physical activity and weekly physical activity levels. A sample of 545 undergraduate students completed an online survey. The analysis of three correlations and three $t$-tests illustrated significant relationships between students' perceptions of the discounted bus pass and their transit-related physical activity, and males' and females' weekly physical activity levels. Three major themes emerged from the open-ended responses, which included the discounted bus pass: (a) is a facilitator of physical activity; (b) is a barrier to physical activity; and (c) does not influence physical activity levels. Therefore, the results suggest that university students who are provided with discounted bus passes may have increased physical activity during their commutes by transit.
\end{abstract}

Keywords: Physical Activity, Health, University Students, Public Transit, Lifestyle 


\section{Acknowledgements}

It was a genuine pleasure and joy to complete this project with the continuous support and assistance of my supervisor, advising committee, friends, and family. I am extremely grateful to the undergraduate students at Western University for their willingness to participate in this study. I would also like to thank all of the staff and faculty members at Western University for providing me with a warm and supportive learning environment.

To my one of a kind supervisor, Dr. Jennifer D. Irwin, it has been a great experience to work with you and learn from you. As my supervisor and mentor, you have inspired me to strive for success and to always be kind to others. Your endless support has been invaluable throughout my journey in graduate school. Thank you so much for everything you have done to help me.

To my advising committee members, Dr. Don Morrow and Dr. Chris Lee, thank you for all of the assistance and feedback you have provided me throughout this project. I am extremely appreciative of all the help you have given me. I can sincerely say without hesitation that it was a pleasure to work with my advising committee members.

I would like to give special thanks to Leigh Vanderloo, Rebecca Fried, and Rebecca Liu for their willingness to always lend a helping hand throughout my research. I am sincerely grateful to have such amazing colleagues who are always willing to provide me with wonderful guidance and feedback. It would have been tough to complete this work without all of your assistance.

I owe a debt of gratitude to Priya, a senior undergraduate research assistant, for all of her help, effort, and dedication. It was an indelible experience to work with you and I truly appreciate all of your hard work. Thank you very much. 
I am thankful to my dearest friends Kevin, Rohan, and John for their unique abilities to know exactly what to do and say, no matter the situation. I am lucky to have such great childhood friends. May the council never break.

Without the support and faith of my family, I would not have the confidence and inspiration to start and finish this project. To Michael, Tommy, and Anna, I am honoured to have such brilliant and admirable siblings. Thank you for all of the constant encouragement and support that you have provided me throughout the years. I would like to extend heartfelt thanks to my grandparents, aunts, and uncles for all of their love, kindness, and reassurance through all of the tough times. And although at times it had been tumultuous, I would like to thank my father for all of the life lessons that he gave to me.

Lastly, I would like to thank my mother who has always been the angel on my shoulder and the sunshine in my life. I am eternally grateful for everything you have done to help me. 


\section{Table of Contents}

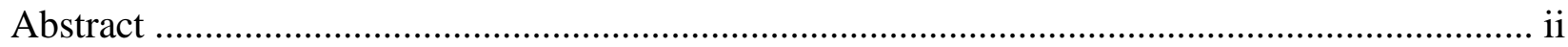

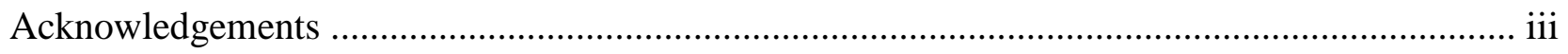

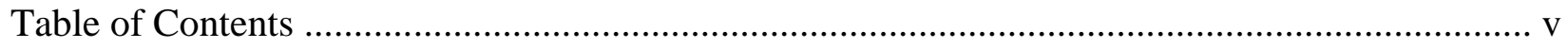

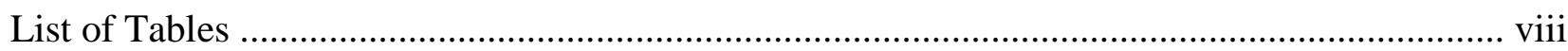

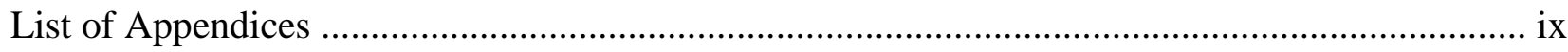

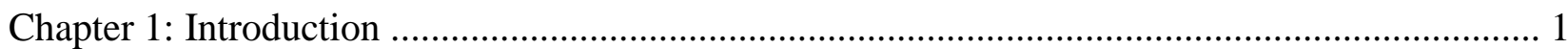

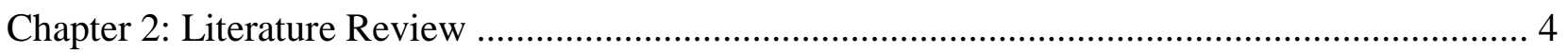

Physical Activity Definition and Guidelines for Health .............................................. 4

University Students' Physical Activity Levels and the Value of Interventions ....................... 5

Active Transportation on University Campuses, the Importance of Targeting Students, and

Public Transit's Potential Role .................................................................................... 7

Considerations for Increasing Public Transit Rates on University Campuses ......................... 9

The Benefits of Unlimited Access to Public Transit ......................................................... 10

Physical Activity and Public Transit ........................................................................... 11

Public Transit at Western University in London (Canada) .............................................. 13

The Development and Continuation of the Western University Bus Pass Program ............... 13

Summary of Evidence Justifying the Study's Focus ....................................................... 16

Purpose and Hypotheses of the Current Study .......................................................... 17

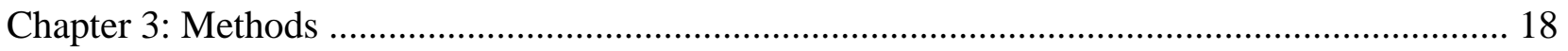

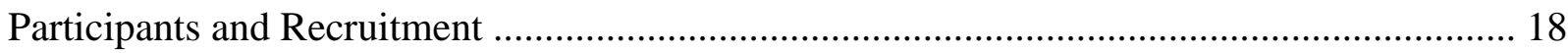

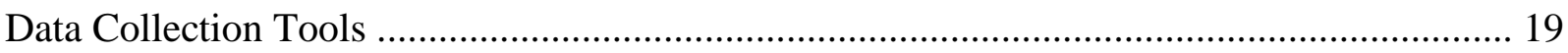

Part A: Perception of Transit-Related Physical Activity Student Survey ......................... 20 
Part B: International Physical Activity Questionnaire-Short Form

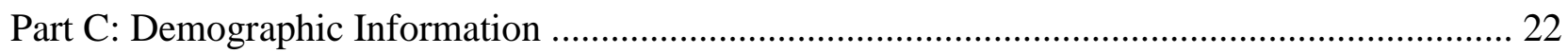

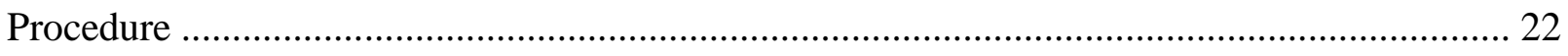

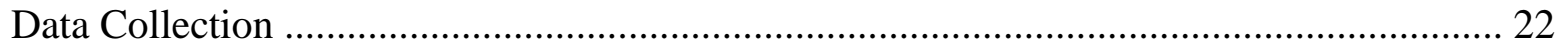

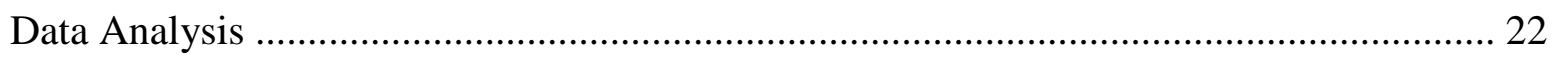

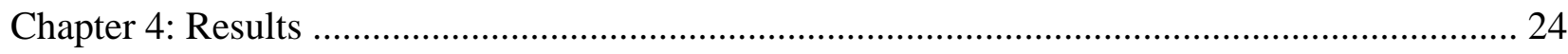

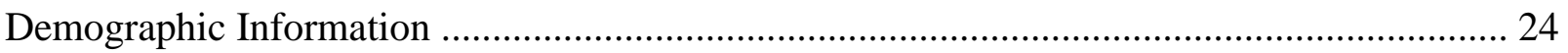

Quantitative Findings from Participants ........................................................................... 27

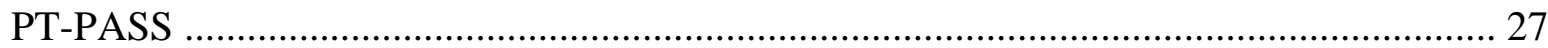

Section One of the PT-PASS: Modes of Transportation ............................................... 27

Section Two of the PT-PASS: Bus Pass and Transit Trips ............................................ 27

Section Three of the PT-PASS: Transit Behaviours ………………………………...... 31

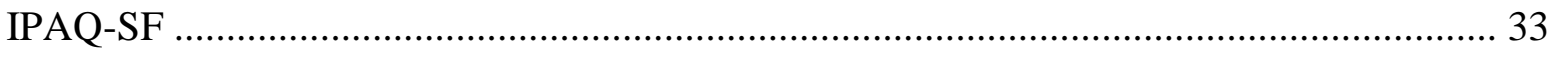

Pearson Bivariate Correlations Utilized to Assess Scores from the PT-PASS and the

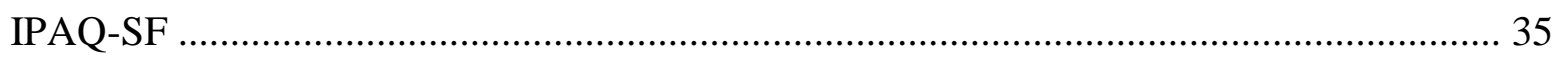

Independent Samples T-Tests Utilized To Assess Sex Differences within the Scores from

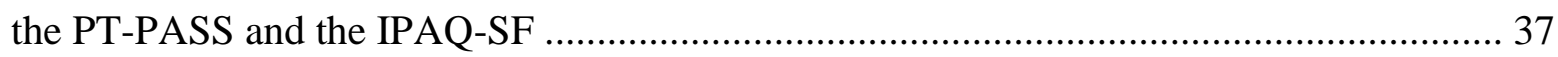

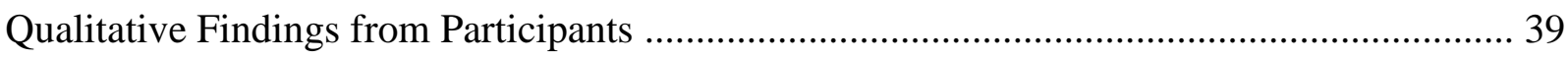

The Discounted Bus Pass is a Facilitator of Physical Activity …………………................. 39

The Discounted Bus Pass is a Barrier to Physical Activity ................................................. 41

The Discounted Bus Pass Does Not Influence University Students' Physical Activity

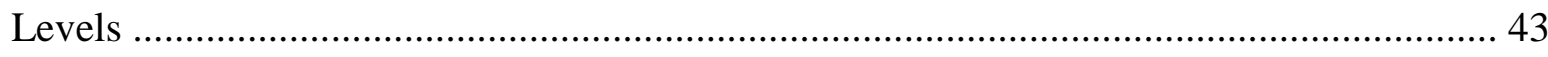

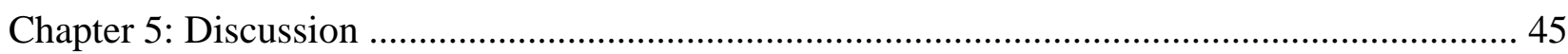




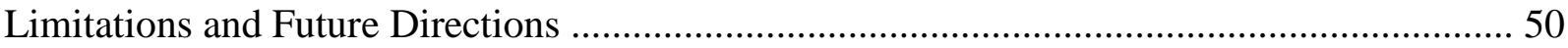

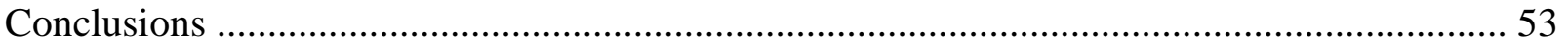

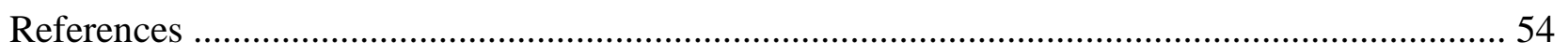

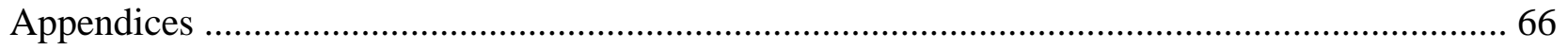

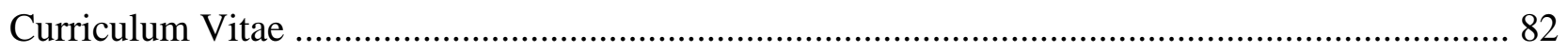




\section{List of Tables}

Table \#

Description

Page

$1 \quad$ Demographic Information

2 Perception of Transit-Related Physical Activity Student Survey

Section 2: Bus Pass and Transit Trips - Students' Perceptions of the Bus Pass

Perception of Transit-Related Physical Activity Student Survey

Section 3: Transit Behaviours - Students' Transit-related Physical

Activity

4

International Physical Activity Questionnaire-Short Form - Students’

Weekly Physical Activity Levels

The Relationships between Students' Scores from the Perception of

Transit-Related Physical Activity Student Survey and the International Physical Activity Questionnaire-Short Form

Transit-Related Physical Activity Student Survey and the International Physical Activity Questionnaire-Short Form Scores

Facilitator of Physical Activity"

8 Quotations Supporting the Theme "The Discounted Bus Pass is a

Barrier to Physical Activity"

Does Not Influence University Students' Physical Activity Levels” 


\section{List of Appendices}

Appendix

Title

Page

A Ethics Approval Notice 66

$\begin{array}{lll}\text { B } & \text { Recruitment Flyer } & 67\end{array}$

C Invitation Email to Course Instructors $\quad 68$

D Letter of Information $\quad 69$

$\begin{array}{lll}\text { E } & \text { Reminder Email to Course Instructors } & 71\end{array}$

$\begin{array}{lll}\text { F The Online Survey } & 72\end{array}$

G International Physical Activity Questionnaire Scoring Protocol 81 (Short Forms) 


\section{Chapter 1: Introduction}

Regular participation in physical activity is a health promoting behaviour with substantive physiological and psychological health benefits for people of all ages (Maglione \& Hayman, 2009; Romaguera et al., 2011). While young adulthood is characterized by the development of individuals' lifestyles, it is also associated with a decline in physical activity levels (Fountaine, Liguori, Mozumdar, \& Schuna, 2011; Keating, Guan, Pinero, \& Bridges, 2005). University students, most of whom are young adults aged 18-24 years (Statistics Canada, 2010), are at risk for insufficiently active lifestyles, thus leading to missed opportunities to gain health benefits that regular participation in physical activity would otherwise provide (Irwin, 2004; Laska, Pelletier, Larson, \& Story, 2012). In addition to promoting good health and being correlated with higher academic performance among students (Keating, Castelli, \& Ayers, 2013), physical activity also serves as a preventative measure for many health problems, including obesity, cardiovascular disease, type II diabetes mellitus, and some cancers (Tremblay et al., 2011; Warburton, Nicol, \& Bredin, 2006). Young adults may obtain health-related benefits from using various modes of active transportation such as walking, biking, or public transit (Besser \& Dannenberg, 2005; Wener \& Evans, 2007). Participation in moderate-intensity physical activity, such as walking to/from public transit stops during daily commutes, might lead to increased physical activity levels for university students (Villanueva, Giles-Corti, \& McCormack, 2008; Wasfi, Ross, \& El-Geneidy, 2013). Hence, a discounted bus pass program could have a meaningful impact on university students' daily physical activity levels. The limited amount of research conducted in this area varies and some authors have even proposed the inverse relationship to be more likely, with discounted bus pass programs being correlated with increased inactivity rates (Edwards et al., 2013; Jones, Steinbach, Roberts, Goodman, \& Green, 
2012). This discrepancy in findings precludes recommendations for discounted bus pass programs within health promotion programming activities, and highlights the need for additional research in this area.

To date, no known Canadian study has been conducted exploring the relationship between a discounted bus pass program and physical activity levels. Full-time undergraduate Western University students receive an unlimited access city bus pass as part of their tuition package. As such, this situation provides a unique opportunity to begin investigating the relationship between university students' physical activity levels and a discounted bus pass program, in a Canadian context. As recommended by McKenzie, Neiger, and Thackeray (2013), a suitable place to begin exploring the potential for any health promotion program is with a needs assessment, which is an appraisal of the target group's self-described views, opinions, and needs. Therefore, the purpose of this study was to assess the relationship between full-time undergraduate Western University students': (a) perceptions of having a discounted bus pass and transit-related physical activity; (b) perceptions of having a discounted bus pass and weekly physical activity levels; and (c) transit-related physical activity and weekly physical activity levels.

The following literature review will include a discussion of the latest Canadian physical activity guidelines followed by a description of what is known about university students' overall levels of physical activity. Then, the importance of university students' lifestyles will be outlined, including examples of health policies that affect students' behaviours on university campuses. Next, the potential benefits and problems of public transit will be explored which leads to an overview of recent recommendations for using/avoiding public transit. Lastly, a 
thorough description of the Western University Bus Pass and London's public transit system will be discussed before the summary of evidence, the study's purpose, and hypotheses are provided. 


\section{Chapter 2: Literature Review}

\section{Physical Activity Definition and Guidelines for Health}

Physical activity is defined as any "movement that increases the heart rate and breathing" (Canadian Society for Exercise Physiology [CSEP], 2012, p. 1) or "any bodily movement produced by skeletal muscles that result in energy expenditure" (Caspersen, Powell, \& Christenson, 1985, p. 126). Different intensity levels of physical activity tend to be relative to an individual's age and capacity to participate (CSEP, 2012). For example, common moderate- to vigorous-intensity physical activities (MVPA) for adults are brisk walking and bicycling, which require movements that will increase their heart rate with minimal sweating (CSEP, 2012). In contrast, sedentary behaviours are defined as "postures or activities that require very little movements" (CSEP, 2012, p. 1), and include activities that involve prolonged sitting such as watching television or extensive computer use (CSEP, 2012). In order to obtain health benefits, adults aged 18-64 years are encouraged to participate in at least 150 minutes of MVPA on a weekly basis, while also reducing sedentary behaviours (CSEP, 2012).

The physiological and psychological health benefits associated with regular physical activity participation among adults are well known (e.g., Pate et al., 1995; Tremblay et al., 2011; Warburton et al., 2006). In particular, adults who follow CSEP's physical activity guidelines can benefit from improved fitness, strength, mental health, as well as maintain a healthy body weight (Tremblay et al., 2011; Warburton et al., 2006). Adherence to these physical activity guidelines are also associated with a reduction in the risk of premature death, cardiovascular diseases, a variety of cancers, type II diabetes mellitus, osteoporosis, and obesity (Haskell et al., 2007; Tremblay et al., 2011). Moreover, individuals with regular physical activity routines may experience improved psychological well-being from reduced levels of anxiety, depression, and 
stress (Warburton et al., 2006). Overall, regular participation in physical activity is a necessary health-promoting behaviour and is needed to achieve numerous health benefits.

\section{University Students' Physical Activity Levels and the Value of Interventions}

Freudenberg et al. (2013) reported that $52.6 \%$ of American undergraduate students do not meet the recommended physical activity guidelines (i.e., 30 minutes of moderate-intensity cardio/aerobic exercise five days per week or 20 minutes of vigorous-intensity cardio/aerobic exercise three days per week; Haskell et al., 2007). In a systematic review of 19 studies, Irwin (2004) described that similar results can be found internationally, with $50 \%$ of students reporting insufficient levels of physical activity. Mirroring these results, Kwan, Cairney, Faulkner, and Pullenayegum (2012) found that there was, on average, a $24 \%$ decrease in physical activity levels among Canadians transitioning from adolescence to early adulthood, with the steepest declines reported among male students enrolled in a college/university. In light of the fact that approximately three fifths of Canadian young adults aged 18-24 years are either currently attending a post-secondary institution or have completed a post-secondary program (Drolet, 2005), it is important for students to increase overall participation in physical activity and reduce inactive lifestyles.

A potential solution for this problem of insufficient activity is the promotion of healthy behaviours via physical activity interventions on university campuses, which have been associated with increased physiological and psychological health benefits such as increases in overall fitness, reduction of stress, and improved academic performance (Freudenberg et al., 2013; Keating et al., 2013). For example, brisk walking included in daily commutes is a form of moderate-intensity aerobic physical activity that contributes to energy expenditure, which, in turn, is a valuable way to improve personal health (Warburton et al., 2006; Wener \& Evans, 
2007). This is illustrated by Tully and Cupples (2011) who found that university students who achieved the daily recommendations of step counts for adults (i.e., 10,000 steps per day, an index used to classify adults as "active"; Tudor-Locke \& Bassett, 2004) had a significant reduction in blood pressure. Also, regular walking behaviours may serve to improve and maintain health with minimal risk of injury, while offering individuals the maximum benefits achieved through regular participation in physical activity (World Health Organization [WHO], 2010). Thus, an increased amount of walking for university students could contribute to overall increases in physical activity levels, which are associated with the promotion of good physical and mental health, as well as increases in academic performance (Besser \& Dannenberg, 2005; Keating et al., 2013; MacDonald, Stokes, Cohen, Kofner, \& Ridgeway, 2010).

Irwin (2007) conducted a longitudinal assessment (baseline and 1-month follow-up) at two Canadian universities and found that only $35 \%$ of undergraduate students $(n=82)$ maintained sufficient amounts of physical activity to meet the guidelines for health. In concert with these prevalence findings, researchers reported that undergraduate students are least satisfied with their physical activity levels, but are highly interested in health promotion programs that aim to improve their levels of physical activity (Tucker \& Irwin, 2011). Similarly, researchers from the University of Manitoba illustrated that fitness and healthy lifestyle programs have been ranked as the highest topics of interest on a health-related assessment among undergraduate students at this institution (Katz, Davis, \& Findlay, 2002). These results emphasize the need for Canadian universities to support campus-based programs that promote physical activity and active lifestyles among undergraduate students. Cholewa and Irwin (2008) implemented a health intervention program at Western University to investigate the effectiveness of a buddy system and record keeping device on students' physical activity behaviours. The 
researchers found that $68.6 \%$ of undergraduate students were active post-intervention, compared to $49 \%$ of students at baseline (Cholewa \& Irwin, 2008). Further, an eight-week pilot study by Kwan, Faulkner, and Bray (2013) completed at the University of Toronto illustrated the potential benefits of a campus-based physical activity program for undergraduate students through an internet-based intervention. An important finding from the study was that $52 \%$ of participants who used the website-delivered physical activity intervention maintained moderate- to vigorousintensity physical activity behaviours compared to $22 \%$ of participants who were non-users of the intervention (Kwan et al., 2013). Hence, these above-noted findings exemplify the potential benefits of campus-based interventions and the need to promote physical activity among Canadian undergraduate students.

Active Transportation on University Campuses, the Importance of Targeting Students, and Public Transit's Potential Role

University students are young adults with multiple responsibilities and, as previously underscored, researchers have found them to be largely insufficiently active (e.g., Deng, Castelli, Castro-Pinero, \& Hongwei, 2011; Irwin, 2007). Keating and colleagues (2005) suggested that universities might need to improve policies and establish interventions and environments that promote healthy behaviours and active lifestyles among the student population. One example of this is from the University of Western Australia, which has promoted physical activity behaviours by attempting to increase active transportation on campus within a transportation demand management (TDM) plan (Shannon et al., 2006). The TDM plan included suggestions for transport policies that may affect students' travel behaviours such as the implementation of a subsidized transit pass program and the increased cost of parking on campus (Shannon et al., 2006). In 2002, the American College Health Association (ACHA) initiated the Healthy Campus 
2010: Making It Happen project, which included policies aimed toward increasing physical activity levels of students in higher education. However, it was found that even after the project was implemented, the majority of students were still not meeting the physical activity guidelines; the final results indicated that only $33.9 \%$ of the students participated in at least three days of moderate physical activity and $28.9 \%$ of the students participated in at least three days of vigorous physical activity (Deng et al., 2011). These examples highlight the need for additional innovative strategies to increase students' physical activity levels. It is important that university administrations consider promoting healthy lifestyles among students during early adulthood, so they can be encouraged to form habits and continue to participate in active behaviours throughout adulthood (Keating et al., 2005).

Policies and interventions targeting university students are particularly important because these individuals are in a position to become the future generations of professionals and knowledge providers (e.g., policymakers, teachers, physicians, etc.) involved in decision making processes that could impact the health of others (Stewart-Brown et al., 2000). Huesman, Brown, Lee, Kellogg, and Radcliffe (2009) described that it is crucial to have a campus that is designed to promote active lifestyles because it may improve academic performances, and thus increase graduation rates. That said, when a campus has already been built and researchers are interested in understanding how best to support the physical activity needs of students, it is necessary to start with a health-related assessment of the student population to determine their perspectives, concerns, and preferences (Katz et al., 2002; McKenzie et al., 2013). The current study will focus on a needs/social assessment specific to transit use. 


\section{Considerations for Increasing Public Transit Rates on University Campuses}

Public transit, also referred to as public transport, is a motorized form of commuting and refers to different modes of travel such as trains or buses (Morency, Trepanier, \& Demers, 2011). The cost of transportation can be expensive for university students who struggle with the costs of tuition and daily living necessities (Brown, Hess, \& Shoup, 2001). If universities do not provide students with unlimited access to transit services (e.g., via a bus pass), on average, it may cost students who live off-campus over $\$ 2,000$ per year in transportation funds (Brown et al., 2001). Universities that provide students with discounted transit programs can reduce their expenses for transportation and overall cost of attending school (Dorsey, 2005). Further, campus-based transit programs are potentially beneficial for universities and the surrounding communities.

The use of public transit has been declining steadily internationally over the past 50 years, while the use of personal vehicles has been increasing (Brown, Hess, \& Shoup, 2003; Dorsey, 2005). Cities and communities have seen the rise of personal vehicles and an increased demand for parking spaces, particularly on university campuses (Barata, Cruz, \& Ferreira, 2011). As a result of the increase in personal vehicles, higher numbers of single occupant vehicles (i.e., no passengers) are on the roads (Shannon et al., 2006). Researchers have stressed that the increase in single occupant vehicles, including on university campuses, is detrimental to society and the environment because traffic congestion increases air pollution and decreases air quality (Brown et al., 2001; Shannon et al., 2006). Brown et al. (2003) suggested that university campuses are focal points for public transit routes, which provide university students with alternative sources of transportation and reduce issues such as parking demands and traffic congestion. Along with the main considerations for environmental benefits, the innovative idea 
of providing students with unlimited access to public transit on university campuses (and beyond) may have additional benefits (Brown et al., 2001; Shannon et al., 2006).

\section{The Benefits of Unlimited Access to Public Transit}

Unlimited access to public transit for university students refers to transit programs that provide individuals with fare-free transit services (Brown et al., 2001). As previously noted, increasing students' access to transit services might decrease the overall cost of attending school for university students, the number of single occupant vehicles, and the demand for parking on campuses (Brown et al., 2001; Shannon et al., 2006). Additionally, unlimited access to transit services can potentially provide students with increased mobility, which will increase their access to low-cost housing and employment opportunities (Brown et al., 2001). Other benefits that some student transit users have reported are higher physical activity levels from increases in daily step counts (e.g., walking to/from bus stops), and improved levels of social inclusion through additional opportunities for interactions with peers such as trips to recreational facilities or sporting events (Jones et al., 2012; Villanueva et al., 2008). The 'social' finding is particularly interesting as researchers described that it is important for campus-based physical activity programs that are targeting undergraduate students to promote social opportunities outside of a structured environment (Burke, Carron, \& Eys, 2006; Tucker \& Irwin, 2006). Moreover, Paez and Whalen (2010) suggested that riding the bus may not only be beneficial to health but also serves as a buffer from home to school/work, which is time that an individual can utilize in order to transition from one place to another by reading a book, listening to music, or talking on a mobile phone. This illustrates that transit users could potentially have a period of relaxation during their commutes to and from school/work. Lastly, universities are influential institutions that often advocate for social equity, and unlimited access to public transit might be important 
for promoting transportation equity among students (Brown et al., 2001). With the focus of the current study being bus pass use and physical activity, the following section will specifically review what is known about this relationship.

\section{Physical Activity and Public Transit}

The definition of active transportation has been recently updated to include daily trips by public transit (Lachapelle \& Frank, 2009; Rissel, Curac, Greenaway, \& Bauman, 2012; Wasifi et al., 2013). Morency et al. (2011) suggested that public transit usage is a form of active transportation because it involves physical activity such as brisk walking to/from transit stops. Moreover, many researchers have indicated that travelling by public transit has many benefits for transit users including additional walking-time during daily transit trips, which could potentially help commuters accumulate higher levels of physical activity (Besser \& Dannenberg, 2005; Edwards, 2008; Shannon et al., 2006). This trend has been observed in a variety of transit users in secondary school, college, and among university students travelling by city buses (Jones et al., 2012; Villanueva et al., 2008; Wasfi et al., 2013). However, there are many factors influencing the relationship between transit use and physical activity that are not well-known.

As illustrated by Morency et al. (2011), travel distance related to transit trips (i.e., how far one has to walk to the bus stop) and multiple transfers during a commute (i.e., switching buses) are factors that can result in additional opportunities for increasing physical activity levels among transit users. In a cross-sectional study, American researchers found that transit users without cars are twice as likely to achieve 30 minutes or more of daily physical activity by walking to/from transit compared to those with access to a personal vehicle as a primary driver (Besser \& Dannenberg, 2005). Additionally, American train users, on average, achieved 30\% more steps than those who commuted by cars, and were more likely to meet the daily 
recommendation of 10,000 steps per day (Wener \& Evans, 2007). Consistent with these findings, Wasifi et al. (2013) found that approximately $11 \%$ of Canadian transit users accumulate 30 minutes of physical activity during their commute to school/work, but Canadians travelling by bus usually achieved fewer steps per commute than train users (Morency et al., 2011). Likewise, Villanueva et al. (2008) concluded that the odds of achieving 10,000 steps per day for university students who commuted by public transit was approximately 4 times higher compared to individuals travelling by cars. A systematic review of 27 articles by Rissel et al. (2012) explored the association between physical activity and public transit use and concluded that public transit may help inactive adults achieve between 8 and 33 minutes of transit-related physical activity. Thus, there has been a growing body of research that indicates transit use might have a positive and substantial influence on adults' activity levels.

The relationship between transit use and physical activity is inconsistent. For instance, Marzoughi (2011) found that Canadians are less likely to walk/bike to school/work if a reliable form of public transit is available (e.g., the Greater Toronto Area). As a result, transit users may miss out on opportunities for physical activity during their daily commutes (Edwards et al., 2013; Jones et al., 2012). Particularly, Jones et al. (2012) suggested students might not benefit from unlimited access to public transit because some individuals only ride for short distances (e.g., students who only travel on the bus for one transit stop), thereby, decreasing their chances for physical activity. In other words, public transit usage may decrease physical activity levels for those who are only using it for short periods instead of walking or biking to their destination. Similarly, Edwards et al. (2013) found that the number of short distance trips made by transit increased from $2 \%$ to $5 \%$ among students (aged 12-17 years) in London, England who were provided with free bus passes. However, it has also been suggested that youths travelling by city 
buses are prone to moving around to talk to their peers or forced to stand when the bus is crowded, which results in higher energy expenditure levels compared to travelling by cars (Jones et al., 2012). Therefore, based on the above-noted research to date, it is unclear whether there are more potential physical activity-related benefits or detriments for university students who regularly commute by public transit. Hence, it is important to further explore this relationship. In the following section, what is already known about the current study's focus on public transit at Western University is outlined.

\section{Public Transit at Western University in London (Canada)}

The City of London is located in southwestern Ontario with a population of 366,000 (Statistics Canada, 2012). Within the centre of London is Western University, with a population of approximately 36,000 part- and full-time students (Western University, 2014). Western University is three kilometres north of downtown London and serves as a public transit hub for city buses operated by the London Transit Commission (LTC). The bus routes expand in all directions from the campus and serve as a key source of transportation for the student population (LTC, 2006). Maintaining and increasing public transit usage has been an important goal to help support the growing city (and student) population (Transport Canada, 2004). In order to meet the growing demands of public transit users, the Western University Bus Pass was first suggested as a possible solution to help maintain and increase ridership in London (LTC, 2006). The discounted bus pass program provides Western University undergraduate students with unlimited access to city buses (LTC, 2006).

\section{The Development and Continuation of the Western University Bus Pass Program}

In Canadian institutions, post-secondary subsidized or discounted public transit passes are often referred to as the U-Pass, ClassPass, Eco Pass, Ed Pass, SuperTicket, Unlimited 
Access, or the Bus Pass (Barata et al., 2011; Brown et al., 2001; Dorsey, 2005; Transport Canada, 2004). Collectively the program is known as the universal transit pass in Canada (Transport Canada, 2008). A discounted transit pass is a 'reduced cost' admission for public transportation services and is less costly than a monthly adult or student transit pass (Canadian Urban Transit Association [CUTA], 2004). At Western University, the LTC offers a discounted transit pass, for full-time Western undergraduate and graduate students (LTC, 2006; Transport Canada, 2004). The Western University Bus Pass is a student-led initiative that was established in 1998 by the University Students' Council (USC) in collaboration with the LTC, and has been ongoing for over 15 years (Transport Canada, 2004). Although some transit agencies have adopted the universal transit pass program, others agencies have failed to implement the program due to lack of student buy-in and support (Toronto Transit Commission [TTC], 2010). Therefore, a significant factor for the success of a discounted transit program is gaining the student council's approval of the initial referendum.

A case study by Transport Canada (2004) highlighted the development of the Western University Bus Pass, which was initially created to reduce the use of automobiles on campus. As such, the Western University Bus Pass program's aim was to increase transit usage and reduce emission from automobiles at this institution. Early challenges for creating the Western University Bus Pass were: (a) working out the details for managing the program; (b) getting undergraduate students' support; (c) creating a referendum; (d) getting Western University's and LTC's administration support; and (e) increasing transit operation to meet the increased ridership demands. The creation of the program was completed by May 1998 and was first implemented during September 1998. There was a 50\% increase in campus ridership after the first year the Western University Bus Pass program was implemented, and a further $20 \%$ increase in overall 
city-wide ridership after three years (Transport Canada, 2004). London experienced overall improvements in public transit services after the creation of the Western University Bus Pass (LTC, 2006). Overall support for the program has continued to increase since the creation of the discounted bus pass, and is still implemented at this institution to this day (Transport Canada, 2004; Western University, 2013a).

The Western University Bus Pass is a discounted adult bus pass that cost $\$ 200$ for the 2013-2014 school year (Western University, 2013a), instead of the \$81 per month adult bus pass available to the public (LTC, 2013). This transit program does not receive financial support from Western University but rather the money comes entirely from the student population (Transport Canada, 2004). In other words, the Western University Bus Pass is a socialized public transit program (i.e., non-transit users subsidize the cost for transit users) that is supported by full-time students. Every student pays an annual fee before the Fall term and Western University only serves as a mediating body that takes in the money and transfers the amount to the USC, which in turn, pays the money to the LTC (Transport Canada, 2004). Brown et al. (2001) argued that in order for universal transit programs to be successful, all students must pay to support the program and only those with special needs may opt out. For example, in order to opt out of the Western University Bus Pass as a full-time undergraduate student, an individual must have a disability that makes him/her eligible for transit services provided for said disability (Transport Canada, 2004). In other words, universal transit programs will not benefit students who are not using the public transit system as their main mode of transportation (Brown et al., 2001). Furthermore, Brown et al. (2001) highlighted that if every student commits to paying for the transit pass, the price of the transit pass will be significantly lowered compared to when students have the option of not paying. Therefore, a contributing factor to the continuous success of the 
Western University Bus Pass program is the willingness of full-time students to pay a single fee at the beginning of each school year.

Annually, Western University undergraduate students receive a special bus pass card and a plastic holder for their bus pass and student photo identification card (USC, 2010). According to the USC (2010), students using the LTC's buses must present their Western University Bus Pass in conjunction with their student identification card in order to utilize the services. Also, each Western University Bus Pass is considered unique because of the student identification number on the card. Since the creation of the Western University Bus Pass for undergraduate students, similar programs have been extended to Western University graduate students and Fanshawe College students in London (Transport Canada, 2004). The significance of the Western University Bus Pass for increasing student mobility, while reducing the use of personal vehicles, has been clearly demonstrated at Western University (Transport Canada, 2004). Although there have been numerous benefits as a result of the Western University Bus Pass program, it is valuable to identify whether or not the discounted bus pass program is associated with increases or decreases in physical activity levels among student transit users.

\section{Summary of Evidence Justifying the Study's Focus}

During early adulthood, there is a decline in physical activity among Canadian university students (Kwan et al., 2012). The potential health-related benefits accumulated through regular participation in physical activity for students have been well-documented (Keating et al., 2013; Tremblay et al., 2011). As such, it is crucial to find ways to increase participation in physical activity and facilitate active lifestyles among Canadian university students (Deng et al., 2011). There is a need to study the impact of a discounted bus pass on students' physical activity levels because evidence is currently contradictory and none to date has been undertaken in a Canadian 
context. Gaining an understanding of the views of the target population is an important first step in making any health promoting program recommendation (McKenzie et al., 2013). Behren, Dinger, Heesch, and Sisson (2005) described that research involving students' perceptions of physical activity-related behaviours provides insight concerning their understanding and awareness of the health benefits that are achievable through health promotion interventions. Thus, it is important to understand university students' perceptions about the discounted bus pass and their physical activity levels.

\section{Purpose and Hypotheses of the Current Study}

The purpose of this study was to assess the relationship between full-time undergraduate Western University students': (a) perceptions of having a discounted bus pass and transit-related physical activity; (b) perceptions of having a discounted bus pass and weekly physical activity levels; and (c) transit-related physical activity and weekly physical activity levels. In line with this, it was hypothesized that: (a) more positive perceptions of the discounted bus pass among undergraduate students' would be correlated with higher transit-related physical activity levels; (b) more positive perceptions of the discounted bus pass among undergraduate students' would be correlated with higher weekly physical activity levels; and (c) higher transit-related physical activity levels among undergraduate students' would be correlated with higher weekly physical activity levels. 


\section{Chapter 3: Methods}

\section{Participants and Recruitment}

The current cross-sectional study included a convenience sample of 545 full-time, male $(n=109)^{1}$ and female $(n=358)^{1}$ undergraduate university students from the host institution. The inclusion criteria for this study were: (a) the individual must be a full-time undergraduate student from Western University; and (b) the individual must be eligible for the Western University Bus Pass in London, Ontario. Recruitment of participants began after receiving ethical approval from the Western University Research Ethics Board at the end of August 2014 (Appendix A). In order to be inclusive, multiple recruitment methods were utilized to invite Western undergraduate students to participate in an online survey. Recruitment flyers (Appendix B) were posted around Western University's campus, and email requests (Appendix C) were sent to course instructors from nine of Western's faculties asking them to consider having the lead researcher make an announcement in their classes and/or post a message on their Sakai course website, Online Western Learning $(O W L)$, inviting students to participate in an online survey. Instructors were chosen purposefully from the Western course calendar in an attempt to obtain a range of disciplines and years of student enrollment. As a means of avoiding any seasonal-related factors such as cold weather and snow that might affect students' perceptions of public transit and the discounted bus pass, participant recruitment concluded at the beginning of November 2014. Emails sent to course instructors included an explanation of the research and contained a link to the survey posted on SurveyMonkey® (SurveyMonkey Inc., 2014). A full explanation of the study was provided to participants in the letter of information that was included at the beginning of the online survey (Appendix D). In an effort to recruit more participants, reminder emails

\footnotetext{
${ }^{1}$ Some participants decided not to disclose their sex in the online survey.
} 
were sent to course instructors who did not reply to the initial invitation email during October 2014 (Appendix E).

There are approximately 27,500 full-time undergraduate students at Western University and its affiliated colleges (Western University, 2013b). As per the inclusion criteria, investigators of this study attempted to recruit as many full-time undergraduate students as possible to complete the online survey during the Fall semester of 2014. The response rate to an online survey by undergraduate students at Canadian Universities is reportedly 13-61\% (Canadian University Survey Consortium [CUSC], 2011). For the current study, response rates were calculated using the number of students enrolled in the participating classes as informed by course instructors and administrative staff. Because several recruitment methods were employed to invite participants to complete the online survey, three response rates were calculated according to whether the course instructors agreed to allow an in-class course announcement, a posting on the course website about the study, or both. There was a 35\% response rate (the total number of students in the courses was 1,574) from students with course instructors who agreed to both an in-class course announcement and a posting on OWL; a 23\% response rate (the total number of students in the courses was 2,411) for instructors who only allowed an in-class course announcement about the study; and a 5\% response rate (the total number of students in the courses was 11,469) for instructors who only posted an invitation to the study on their OWL website. However, some course instructors who were contacted belong to the same faculty and it was possible that the same students were included multiple times in the response rates.

\section{Data Collection Tools}

The online survey sent to students included parts A, B, and C as outlined below: 


\section{Part A: Perception of Transit-Related Physical Activity Student Survey. The} Perception of Transit-Related Physical Activity Student Survey (the PT-PASS was part of the online survey; Appendix F) included pointed bus pass-related questions (e.g., frequency of use, perceptions of its physical activity influence) and was developed by the investigators for this study. The PT-PASS was a self-administered survey containing three sections (i.e., Modes of Transportation, Bus Pass and Transit Trips, and Transit Behaviours), and was comprised of 44 questions answered on a five-point Likert scale (i.e., strongly disagree, disagree, neither disagree nor agree, agree, strongly agree) and one open-ended question (i.e., The purpose of this survey is to assess Western undergraduate students' perceptions of how having a discounted bus pass might influence their physical activity levels. Please use the space below to provide any comments you might have regarding this topic.). Individuals' perceptions of the Western University Bus Pass and transit-related physical activity behaviours were calculated from items in the PT-PASS, which were summed and averaged accordingly (e.g., the anchor scores are [1] strongly disagree and [5] strongly agree). This survey contained no reverse coding for any questions and students were advised to choose the most appropriate response for each question.

The first section of the PT-PASS asked students about their commuting habits and this section was used to report Western undergraduates' general preferences for different modes of transportation. Section two of the PT-PASS was used to determine Western undergraduate students' perceptions of the discounted bus pass, and section three assessed their transit-related physical activity behaviours. The questions were adapted from previously validated transit surveys (e.g., LTC, 2006; Paez et al., 2010; Shannon et al., 2006) and new questions were also written specifically to address the current study's purpose. The survey was pilot-tested with 10 Western undergraduate students and five graduate students to assess face validity. Investigators 
engaged with students while they were completing the survey and/or asked them to make notes on the survey to find out what they thought/interpreted about the questions and their meaning. The questions were modified or deleted from the survey based on students' suggestions and comments. This process helped to ensure the questions were appropriate in content and wording, and accurately reflected what they were intended to assess.

Part B: International Physical Activity Questionnaire-short form. Undergraduate students' weekly physical activity levels were measured using the International Physical Activity Questionnaire-short form (IPAQ-SF; IPAQ, 2002). This self-reported questionnaire contained seven items that required the participants to answer each question based on their physical activity levels within the last seven days (the IPAQ-SF was included in the online survey; Appendix F). Participants answered the questions by inputting a number for the amount of minutes, hours, or days they spent engaged in physical activity within the previous week. The IPAQ-SF measured physical activity levels in metabolic equivalent of task (MET; Craig et al., 2003) and the items were scored using the following equation from the 2005 revised MET equivalent guidelines: total MET-minutes/week $=[$ walking (3.3 METs x minutes x days) $]+[$ moderate intensity $(4$ METs x minutes x days)] + [vigorous intensity (8 METs x minutes x days)] (IPAQ, 2005; Appendix G). Subsequently, participants were categorized as either having low (0-599 METminutes/week), moderate (600-2999 MET-minutes/week), or high ( $\geq 3000$ MET-minutes/week) levels of physical activity. The data processing rules from the 2005 guidelines were used to clean the results gathered from the online survey. The IPAQ-SF is an established questionnaire that has been used in many studies internationally (Craig et al., 2003). The test re-test reliability of the IPAQ-SF was previously reported as a correlation coefficient of .76 and the criterion validity as .30 (Craig et al., 2003). 
Part C: Demographic information. The last part of the online survey consisted of nine questions (Appendix F) to gather personal information (e.g., sex, age, ethnicity, enrollment status, etc.) about the participants from this study. The information gathered from this section was used for descriptive purposes such as determining differences between male and female transit users. Furthermore, demographic information such as students' enrollment status helped investigators to ensure that inclusion criteria were being met (i.e., individuals who reported that they were part-time students were eliminated from the data analysis).

\section{Procedure}

Data collection. As noted above, data collection began during the last week of August 2014 (i.e., the online survey link was activated) and ended at the beginning of November 2014 (i.e., the online survey link was deactivated), in order to avoid possible winter-related transportation barriers. Students who participated by clicking on the survey link were informed that their decision to complete the survey constituted consent. The complete online survey contained 61 questions, which took respondents approximately 10 minutes to complete. Honesty demands were used and included in the instructions of the survey (Bates, 1992); participants were asked to complete the survey by selecting the most appropriate response to each question that best reflected their feelings, and thus helped decrease social desirability effects. Participants were also advised that they may skip questions and could withdraw from the study at anytime without any penalty (academically or otherwise). There was no time limit to complete the online survey.

Data analysis. The analyses of this study included full-time undergraduate students who received the discounted bus pass as part of their tuition package from Western University. All raw data were aggregated and entered into spreadsheets (Microsoft Excel, 2013) and word 
documents (Microsoft Word, 2013). Multiple answers to a close-ended question were automatically resolved using functions from Microsoft Excel, which only included the first value from a data set (e.g., if agree and strongly agree were entered then agree would be included and strongly agree would be deleted from the aggregated data). Missing data were treated as randomly missing or a value of zero as per instructions from the IPAQ 2005's scoring protocol. Descriptive statistics were used to investigate the relationships from data gathered in this study, and were analyzed using IBM SPSS (version 22, 2013). Demographic information was utilized to ensure that participants met the eligibility criteria and for implications of the study's generalizability (external validity). Also, investigators analyzed demographic data to determine whether there were any differences between male and female transit users. Pearson bivariate correlations $(\alpha=.05)$ were used to investigate the relationships between: (a) students' perceptions of the Western University Bus Pass and transit-related physical activity behaviours; (b) students' perceptions of the Western University Bus Pass and weekly physical activity levels; and (c) students' transit-related physical activity behaviours and weekly physical activity levels. Further, answers from one open-ended question were recorded in Microsoft Excel (2013) and Microsoft Word (2013) and inductive content analysis (as described by Patton, 2002) was performed in order to identify common themes frequently mentioned by participants. To further support the developed themes, QSR International NVivo (version 10, 2012) 'Word Frequency' query was used to confirm that significant words from the developed themes were frequently mentioned in the short answer responses. Lastly, a minimum of 35\% of each aggregated data set ( 200 responses for each data set) were checked for errors as part of the data cleaning process that was performed by the investigators and a senior undergraduate research assistant. 


\section{Chapter 4: Results}

The findings from the data analysis, which produced both quantitative and qualitative data, are discussed in this section. Firstly, demographic information of the population is presented below. Then, the quantitative findings from the online survey are provided and illustrated through statistical tables. Lastly, the qualitative findings from one open-ended question are discussed using supporting quotations for each of the three different themes identified.

\section{Demographic Information}

Because participants were allowed to skip questions that were asked in the online survey (i.e., some individuals chose not to disclose certain personal information about themselves), the resulting information in Table 1 does not always reflect the total number of participants who completed the online survey $(N=545)$. Seven undergraduate students with part-time enrollment status were excluded from the data analysis because they did not meet the inclusion criteria (i.e., full-time undergraduate students who received the discounted bus pass). Consequently, the following data analyses included 538 full-time undergraduate students. More female $(n=358)$ undergraduate students participated in the online survey than male students, and the majority of participants were Caucasian $(n=303)$. The respondents' ages ranged from 19 years and under $(n$ $=265)$ to 50 years and over $(n=1)$. Most participants were enrolled in their second year of university $(n=228)$ and were from either the Faculty of Health Sciences $(n=169)$ or Faculty of Science $(n=143)$. The majority of students were not employed $(n=311)$ and living off-campus with roommates $(n=281)$ in London, Ontario for the Fall and Winter semesters only $(n=323)$. Table 1 summarizes the demographic information collected from Western undergraduate students who participated in the online survey. 
Table 1

Demographic Information $(N=545)$

\begin{tabular}{|c|c|c|}
\hline Characteristic & $n$ & $\%$ \\
\hline \multicolumn{3}{|l|}{ Sex } \\
\hline Male & 109 & 20.00 \\
\hline Female & 358 & 65.69 \\
\hline Other & 3 & .55 \\
\hline Prefer not to disclose & 3 & .55 \\
\hline \multicolumn{3}{|l|}{ Age } \\
\hline 19 years and under & 265 & 48.62 \\
\hline $20-24$ years & 193 & 35.41 \\
\hline $25-29$ years & 8 & 1.47 \\
\hline $30-34$ years & 3 & .55 \\
\hline $35-39$ years & 0 & .00 \\
\hline $40-44$ years & 1 & .18 \\
\hline 45-49 years & 0 & .00 \\
\hline 50 years and over & 1 & .18 \\
\hline \multicolumn{3}{|l|}{ Ethnicity } \\
\hline Aboriginal & 3 & .55 \\
\hline African Heritage & 8 & 1.47 \\
\hline Caucasian & 303 & 55.60 \\
\hline East Asian & 55 & 10.09 \\
\hline Hispanic & 10 & 1.83 \\
\hline Middle Eastern & 20 & 3.67 \\
\hline South Asian & 51 & 9.36 \\
\hline Other & 32 & 5.87 \\
\hline \multicolumn{3}{|l|}{ Enrollment Status } \\
\hline Part-time & $7^{*}$ & $1.28^{*}$ \\
\hline Full-time & 461 & 84.59 \\
\hline \multicolumn{3}{|l|}{ Program of Registration } \\
\hline Faculty of Arts and Humanities & 23 & 4.22 \\
\hline Faculty of Education & 1 & .18 \\
\hline Faculty of Engineering & 20 & 3.67 \\
\hline Faculty of Health Sciences & 169 & 31.01 \\
\hline Faculty of Information and Media Studies & 37 & 6.79 \\
\hline Faculty of Music & 2 & .37 \\
\hline Faculty of Science & 143 & 26.24 \\
\hline Faculty of Social Science & 76 & 13.94 \\
\hline Ivey Business School & 3 & .55 \\
\hline Other & 5 & .92 \\
\hline
\end{tabular}


Year of Academic Enrollment

First

73

228

81

75

6

5

\section{1}

157

4

323

London, Ontario (Fall and Winter semesters only)

London, Ontario (year round)

Outside of London, Ontario

Living Arrangement

On campus

Off-campus alone

Off-campus with roommates

Off-campus with relatives

$\begin{array}{ll}3 & 13.39 \\ 28 & 41.83 \\ 1 & 14.86 \\ 75 & 13.76 \\ 6 & 1.10 \\ & .92\end{array}$

57.06

28.81

.73

Note. Responses may not reflect the total number of participants, and thus, not all percentages add up to a hundred percent due to responses received. ${ }^{*}$ These participants were removed from data analyses because they did not meet the inclusion criteria (i.e., they were not full-time undergraduate students). 


\section{Quantitative Findings from Participants}

Quantitative findings from the PT-PASS and IPAQ-SF were analyzed using SPSS

(version 22, 2013) and Microsoft Excel. The descriptive statistical analysis focused on three bivariate Pearson correlations and three independent samples $t$-tests. The correlations focused on the relationships between students' perceptions of the bus pass, transit-related physical activity, and weekly physical activity levels. The $t$-tests determined whether any sex differences existed within the relationships calculated from the PT-PASS and IPAQ-SF scores.

PT-PASS. The data from three different sections of the PT-PASS were analyzed and are reported below. Sections two and three of the PT-PASS were used to generate two-tailed Pearson correlations and two-tailed independent samples $t$-tests.

Section one of the PT-PASS: Modes of transportation. This section of the PT-PASS gathered information about how Western undergraduate students may choose to commute and

their access to different modes of transportation. Respondents reported that they walked and used the bus regularly to get to school, at $52.60 \%$ and $62.83 \%$ respectively, and less than one fifth $(19.70 \%)$ reported that they often used a car even though approximately one third (33.27\%) had access to one (with $8.36 \%$ having a campus parking permit). Although $32.90 \%$ reported having a bicycle they could use, just over $8 \%$ reported riding a bike to school on a regular basis. Of interest, more than $80 \%$ of students who used the bus reached their destination without the need to transfer to a different bus.

Section two of the PT-PASS: Bus pass and transit trips. All participants who completed the online survey had a score for this section $(n=538,100 \%)$. The average score for participants' perceptions of the bus pass was $M=3.48(S D=0.53)$ reflecting a slight favour of 
public transit and the Western University Bus Pass. The mean scores and their respective standard deviations are presented in Table 2 . 
Table 2

Perception of Transit-Related Physical Activity Student Survey Section 2: Bus Pass and Transit

Trips - Students' Perceptions of the Bus Pass

\begin{tabular}{|c|c|c|c|c|}
\hline & Item & $n$ & $M$ & $S D$ \\
\hline 1 & $\begin{array}{l}\text { Public transit trips are enjoyable transitions between home and } \\
\text { school/work. }\end{array}$ & 537 & 2.69 & 0.93 \\
\hline 2 & $\begin{array}{l}\text { I am comfortable being around strangers when I travel by public } \\
\text { transit. }\end{array}$ & 537 & 3.47 & 0.91 \\
\hline 3 & $\begin{array}{l}\text { I travel by public transit because my friends/colleagues use this } \\
\text { mode of transportation. }\end{array}$ & 538 & 2.39 & 1.02 \\
\hline 4 & $\begin{array}{l}\text { It is convenient to travel by public transit when I have a lot to } \\
\text { carry (e.g., gym bags, grocery bags, etc.). }\end{array}$ & 538 & 2.65 & 1.42 \\
\hline 5 & I travel by public transit when it is cold or raining outside. & 538 & 3.93 & 1.03 \\
\hline 6 & $\begin{array}{l}\text { The public transit in my area is usually comfortable, clean, and } \\
\text { well-maintained. }\end{array}$ & 538 & 3.52 & 0.91 \\
\hline 7 & I feel safe to use public transit at night. & 538 & 3.49 & 1.01 \\
\hline 8 & $\begin{array}{l}\text { The public transit services in my area are reliable (e.g., sufficient } \\
\text { services, never late, available every day of the week, etc.). }\end{array}$ & 533 & 2.72 & 1.13 \\
\hline 9 & I feel safe when walking to the transit stop in my neighbourhood. & 537 & 3.91 & 0.82 \\
\hline 10 & $\begin{array}{l}\text { I often use public transit to travel to places I can be physically } \\
\text { active (e.g., gym, fitness studios, etc.). }\end{array}$ & 535 & 2.81 & 1.12 \\
\hline 11 & I often use my Western University Bus Pass. & 536 & 4.20 & 1.10 \\
\hline 12 & I use public transit because of my Western University Bus Pass. & 535 & 4.15 & 1.01 \\
\hline 13 & $\begin{array}{l}\text { I am in favour of Western University Bus Pass program for } \\
\text { undergraduate students. }\end{array}$ & 537 & 4.61 & 0.74 \\
\hline 14 & I use my Western University Bus Pass to save money. & 537 & 4.25 & 1.00 \\
\hline 15 & $\begin{array}{l}\text { I can travel anywhere in the city using my Western University } \\
\text { Bus Pass. }\end{array}$ & 534 & 3.68 & 1.12 \\
\hline 16 & $\begin{array}{l}\text { I travel by car less often because I have my Western University } \\
\text { Bus Pass. }\end{array}$ & 535 & 3.45 & 1.24 \\
\hline 17 & $\begin{array}{l}\text { I have additional opportunities to travel because my Western } \\
\text { University Bus Pass provides unlimited access to public transit. }\end{array}$ & 535 & 3.78 & 1.06 \\
\hline 18 & $\begin{array}{l}\text { I often travel to appointments (e.g., job interviews, medical } \\
\text { assessments, etc.) and complete errands (e.g., shopping for } \\
\text { groceries, returning library books, etc.) using my Western } \\
\text { University Bus Pass. }\end{array}$ & 534 & 3.39 & 1.30 \\
\hline 19 & $\begin{array}{l}\text { I have the opportunity to participate in leisure activities because } \\
\text { of my Western University Bus Pass. }\end{array}$ & 532 & 3.52 & 1.04 \\
\hline 20 & $\begin{array}{l}\text { I use my Western University Bus Pass to travel by public transit } \\
\text { because it is more environmentally friendly than travelling by car. }\end{array}$ & 533 & 3.08 & 1.13 \\
\hline
\end{tabular}


Note. Items were on a five-point Likert scale and anchor scores were (1) strongly disagree and (5) strongly agree; $n=$ number of participants that responded to the question and were included in the analysis; $M=$ mean score $S D=$ standard deviation. 
Section three of the PT-PASS: Transit behaviours. The majority of participants who completed the online survey had a score for this section $(n=535,99.44 \%)$ with the exception of three individuals whose scores were excluded from the analysis because they opted not to complete this section of the survey. The mean score of students' transit-related physical activity was $M=3.13(S D=.46)$, suggesting participants' perceived that public transit does have a small positive influence on their physical activity levels. The mean scores and the standard deviations for each question from section 3 of the PT-PASS are in Table 3. 
Table 3

Perception of Transit-Related Physical Activity Student Survey Section 3: Transit Behaviours Students’ Transit-related Physical Activity

\begin{tabular}{|c|c|c|c|c|}
\hline & Item & $n$ & $M$ & $S D$ \\
\hline 1 & Walking to the bus stop helps make me more active. & 534 & 3.12 & 1.09 \\
\hline 2 & $\begin{array}{l}\text { I spend more time walking when I use public transit than when I } \\
\text { drive. }\end{array}$ & 534 & 3.93 & 0.94 \\
\hline 3 & $\begin{array}{l}\text { I rarely use my Western University Bus Pass to ride the bus for } \\
\text { short distances (e.g., one or two stops). }\end{array}$ & 533 & 3.76 & 1.17 \\
\hline 4 & $\begin{array}{l}\text { If I am early for my bus, I will walk to a different bus stop (i.e., } \\
\text { one that is farther away). }\end{array}$ & 533 & 2.63 & 1.11 \\
\hline 5 & When I miss the bus, I will walk to the next bus stop on my route. & 534 & 2.84 & 1.13 \\
\hline 6 & I enjoy walking to/from the bus stop. & 533 & 3.09 & 1.03 \\
\hline 7 & $\begin{array}{l}\text { When I transfer from one bus to another, I often have to run to } \\
\text { catch my next bus. }\end{array}$ & 532 & 2.91 & 0.85 \\
\hline 8 & I often walk around the bus stop area while I wait for the bus. & 534 & 2.88 & 1.08 \\
\hline 9 & $\begin{array}{l}\text { When I use my Western University Bus Pass, I often accumulate } \\
30 \text { minutes of walking during my transit trip(s). }\end{array}$ & 533 & 2.85 & 1.09 \\
\hline 10 & I rarely sit for long periods when I use the bus. & 533 & 3.08 & 1.01 \\
\hline 11 & I often have/choose to stand in the bus. & 531 & 3.40 & 1.01 \\
\hline 12 & $\begin{array}{l}\text { My Western University Bus Pass often helps increase my overall } \\
\text { physical activity levels. }\end{array}$ & 530 & 2.87 & 1.02 \\
\hline 13 & I usually walk quickly to catch the bus. & 535 & 3.83 & 0.86 \\
\hline 14 & I often bike to a bus stop. & 532 & 1.48 & 0.68 \\
\hline 15 & I rarely get driven to a bus stop. & 535 & 4.42 & 1.02 \\
\hline 16 & I walk more often because of my Western University Bus Pass. & 534 & 3.13 & 1.12 \\
\hline 17 & $\begin{array}{l}\text { Using public transit is a way to accumulate physical activity } \\
\text { during my daily commutes. }\end{array}$ & 532 & 3.01 & 1.11 \\
\hline
\end{tabular}

Note. Items were on a five-point Likert scale and anchor scores were (1) strongly disagree and (5) strongly agree; $n=$ number of participants that responded to the question and were included in the analysis; $M=$ mean score; $S D=$ standard deviation. 
IPAQ-SF. All participants who completed the online survey had a score for this section $(n=538,100 \%)$. The IPAQ-SF was used to calculate two-tailed Pearson correlations and twotailed independent samples $t$-tests. Blank answers left by students were treated as zeroes (as directed by the Guidelines for Data Processing and Analysis of the IPAQ, 2005). The average score for respondents' weekly physical activity levels was $M=3086.43$ MET-minutes/week (SD = 3255.46 MET-minutes/week), which indicated that the majority of respondents had a high level of physical activity during the past seven days (Guidelines for Data Processing and Analysis of the IPAQ, 2005). Participants' IPAQ-SF scores range from 0-22,050 METminutes/week. Table 4 contains the mean scores and standard deviations of each question from the IPAQ-SF. 
Table 4

International Physical Activity Questionnaire-Short Form - Students' Weekly Physical Activity

Levels

\begin{tabular}{|c|c|c|c|c|}
\hline & Item & $n$ & $M$ & $S D$ \\
\hline 1 & $\begin{array}{l}\text { During the last } 7 \text { days, on how many days did you do } \\
\text { vigorous physical activities like heavy lifting, digging, } \\
\text { aerobics, or fast bicycling? }\end{array}$ & 383 & $2.71^{*}$ & $1.95^{*}$ \\
\hline 2 & $\begin{array}{l}\text { How much time did you usually spend doing vigorous } \\
\text { physical activities on one of those days? }\end{array}$ & 538 & $43.82^{\dagger}$ & $48.50^{\dagger}$ \\
\hline 3 & $\begin{array}{l}\text { During the last } 7 \text { days, on how many days did you do } \\
\text { moderate physical activities like carrying light loads, } \\
\text { bicycling at a regular pace, or doubles tennis? Do not } \\
\text { include walking. }\end{array}$ & 381 & $3.03^{*}$ & $2.21^{*}$ \\
\hline 4 & $\begin{array}{l}\text { How much time did you usually spend doing moderate } \\
\text { physical activities on one of those days? }\end{array}$ & 538 & $46.53^{\dagger}$ & $59.64^{\dagger}$ \\
\hline 5 & $\begin{array}{l}\text { During the last } 7 \text { days, on how many days did you walk } \\
\text { for at least } 10 \text { minutes at a time? }\end{array}$ & 431 & $6.20^{*}$ & $1.43^{*}$ \\
\hline 6 & $\begin{array}{l}\text { How much time did you usually spend walking on one of } \\
\text { those days? }\end{array}$ & 538 & $53.29^{\dagger}$ & $60.25^{\dagger}$ \\
\hline 7 & $\begin{array}{l}\text { During the last } 7 \text { days, how much time did you spend } \\
\text { sitting on a week day? }\end{array}$ & 538 & $338.41^{\ddagger}$ & $235.77^{\ddagger}$ \\
\hline
\end{tabular}

Note. The above scores do not include the calculated scores in MET-minutes/week. $n=$ number of participants that responded to the question and were included in the analysis; $M=$ mean score; $S D=$ standard deviation; ${ }^{*}$ value in days; ${ }^{\dagger}$ value in minutes per day; ${ }^{\dagger}$ value in minutes per week day. 


\section{Pearson bivariate correlations utilized to assess scores from the PT-PASS and the}

IPAQ-SF. As shown in Table 5, one out of the three two-tailed Pearson correlations was significant at $p<.05$. Students' perceptions of the discounted bus pass and their transit-related physical activity had a significant and positive relationship at $[r(533)=.44, p<.001]$ with a $R^{2}=$ .19 (see Table 5). The coefficient of determination $\left(R^{2}\right)$ for the correlation between perceptions of bus pass and transit-related physical activity was calculated to be $R^{2}=.19$ (a medium to large effect size according to Cohen [1988]), indicating that $19 \%$ of the variance in public transitrelated physical activity can be explained by the participants' perceptions of the discounted bus pass. Table 5 also shows two non-significant correlations between IPAQ scores and perceptions of the bus pass $[r(536)=-.04, p=.18]$, and IPAQ scores and transit-related physical activity $[r(533)=.02, p=.37]$. Thus, Western undergraduate students' perceptions of the discounted bus pass had an influence on their transit-related physical activity but not on their weekly physical activity levels. 
Table 5

The Relationships between Students' Scores from the Perception of Transit-Related Physical Activity Student Survey and the International Physical Activity Questionnaire-Short Form

\begin{tabular}{|c|c|c|c|c|c|}
\hline Measure & $n$ & $M$ & $S D$ & $\begin{array}{l}\text { Transit-related } \\
\text { Physical Activity }\end{array}$ & $\begin{array}{l}\text { Weekly Physical } \\
\text { Activity Levels }\end{array}$ \\
\hline $\begin{array}{l}\text { Perception of } \\
\text { Bus Pass }\end{array}$ & 538 & 3.48 & 0.53 & $.44^{*}$ & -.04 \\
\hline $\begin{array}{l}\text { Transit-related } \\
\text { Physical Activity }\end{array}$ & 535 & 3.13 & 0.46 & - & .02 \\
\hline $\begin{array}{l}\text { Weekly Physical } \\
\text { Activity Levels } \\
\text { (MET-minutes/week) }\end{array}$ & 538 & 3086.43 & 3255.46 & - & - \\
\hline
\end{tabular}

Note. $n=$ number of participants that responded to the question and were included in the analysis; $M=$ mean score $S D=$ standard deviation; $\stackrel{*}{p}<.001$ (2-tailed). 


\section{Independent samples $t$-tests utilized to assess sex differences within the scores from}

the PT-PASS and the IPAQ-SF. As illustrated in Table 6, one out of the three two-tailed $t$-tests that were used to assess sex differences between scores was significant at $p<.05$. IPAQ scores (i.e., weekly physical activity levels) among Western undergraduate students significantly differed based on sex, $[t(458)=2.06, p<.05]$, with male students $(n=107, M=4231.13$ METminutes/week, $S D=3957.38$ MET-minutes/week) scoring higher than female students $(n=353$, $M=3377.87$ MET-minutes/week, $S D=2990.88$ MET-minutes/week). Table 6 also indicated no statistically significant relationship between males' and females' perceptions of the bus pass scores $[t(458)=1.07, p=.29]$ with slightly higher scores for males $(n=107, M=3.55, S D=$ $0.58)$ than females $(n=353, M=3.49, S D=0.50)$. Lastly, there was no statistically significant relationship between males' $(n=107, M=3.14, S D=.51)$ and females' $(n=352, M=3.13, S D$ $=.46)$ transit-related physical activity scores $[t(457)=.04, p=.97]$. 
Table 6

Sex Differences within the Relationships between the Perception of Transit-Related Physical Activity Student Survey and the International Physical Activity Questionnaire-Short Form Scores

\begin{tabular}{|c|c|c|c|c|c|c|c|}
\hline \multirow[b]{2}{*}{ Measure } & \multicolumn{3}{|c|}{ Males } & \multicolumn{3}{|c|}{ Females } & \multirow[b]{2}{*}{$t$} \\
\hline & $n$ & $M$ & $S D$ & $n$ & $M$ & $S D$ & \\
\hline $\begin{array}{l}\text { Perception of } \\
\text { Bus Bass }\end{array}$ & 107 & 3.55 & 0.58 & 353 & 3.49 & 0.50 & 1.07 \\
\hline $\begin{array}{l}\text { Transit-related } \\
\text { Physical Activity }\end{array}$ & 107 & 3.14 & 0.51 & 352 & 3.13 & 0.46 & .04 \\
\hline $\begin{array}{l}\text { Weekly Physical } \\
\text { Activity Levels } \\
\text { (MET-minutes/week) }\end{array}$ & 107 & 4231.13 & 3957.38 & 353 & 3377.87 & 2990.88 & $2.06^{*}$ \\
\hline
\end{tabular}

Note. $n=$ number of participants that responded to the question and were included in the

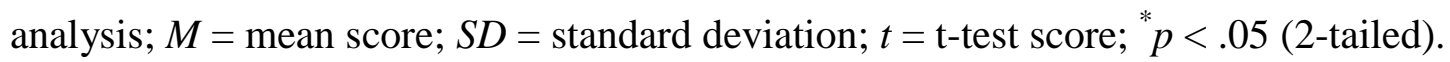




\section{Qualitative Findings from Participants}

Qualitative data from one open-ended question in the PT-PASS (i.e., The purpose of this survey is to assess Western undergraduate students' perceptions of how having a discounted bus pass might influence their physical activity levels. Please use the space below to provide any comments you might have regarding this topic.) were analyzed using inductive content analysis (Patton, 2002). To enhance the confirmability of the qualitative analysis process and to ensure the trustworthiness of the data, the lead researchers and a trained senior undergraduate research assistant independently reviewed the comments, coded the data, and identified themes (as described by Guba and Lincoln, 1989). Then, they met to discuss and agree upon the themes presented in Tables 7, 8, and 9. The three themes identified were: the discounted bus pass is a facilitator of physical activity; the discounted bus pass is a barrier to physical activity; and the discounted bus pass does not influence university students’ physical activity levels.

\section{The discounted bus pass is a facilitator of physical activity. Many participants} described that the discounted bus pass had a positive influence on their physical activity levels in numerous ways such as getting more walking done during commutes, additional opportunities to travel to the gym, and less dependence on personal vehicles. Additionally, some students expressed that they genuinely enjoy having unlimited access to transit via their discounted bus pass during bad weather, heavy traffic, and when "carrying heavy bags". Thus, some credited the Western University Bus Pass as providing access to a reliable mode of transportation that helps them to achieve additional opportunities for physical activity during their daily commutes. Supporting quotations that best exemplify the respondents' answers and illustrate this theme are presented in Table 7. 
Table 7

Quotations Supporting the Theme "The Discounted Bus Pass is a Facilitator of Physical Activity”

"I am definitely conscious of the fact that I walk more when I use public transit. And I am very thankful it is provided to students at a discount. In fact, when I worry that I am not getting enough exercise, I am relieved to remember that walk to and from the bus [stop] brings some (however small) measure of physical activity into my life."

"Having a public transit option encourages people to avoid driving everywhere and walk to their bus stops. It is an easy way to get exercise while still being practical on poor-weather days and when carrying heavy bags."

"I think that by offering Western's undergrads a discounted bus pass; people that are already active are able to stay active or be more active because of increased opportunities, ect, [...]"

"Cheap access to public transit convinced me to keep my car at home. I definitely believe I am more physically active without my car."

"The discounted bus pass is a really great idea for Western students and I fully support it... It has made me more active in my walk to and from the bus stop when otherwise I would have driven somewhere."

"Having a discounted bus pass could encourage more students to use the bus and therefore do more walking to and from bus stops, rather than just walking to the car in the driveway."

"I do walk more because of my bus pass which is not a terrible thing. It allows me to have a relaxing trip to campus when weather or traffic is terrible."

"Having my bus pass is the only way I can get to the gym especially in the winter."

"For the days I do not have time for the gym, having my bus pass and taking the bus enables me to at the very least, do a brisk walk to the stop."

Note. This table contains the most relevant quotations that reflect this theme. 
The discounted bus pass is a barrier to physical activity. Some respondents disclosed that the mandatory discounted bus pass tends to be a barrier for their participation in physical activity during their daily commutes, such as fewer opportunities for walking or biking to school. Several students mentioned that without access to the discounted bus pass they would be more likely to bike to school and less likely to take public transit for short distances (e.g., riding the bus for only 10-15 minutes). Hence, some participants believed that having the Western University Bus Pass that provided them with unlimited access to public transit have made them more "lazy" during their daily commutes. Supporting quotations that best represent this theme are displayed in Table 8. 
Table 8

Quotations Supporting the Theme "The Discounted Bus Pass is a Barrier to Physical Activity"

"... if there was no UWO bus pass, I think people would resort to more physically active modes of transport, such as biking, running, etc. Additionally, I find that some students who do live very close to campus misuse the UWO bus pass owing to pure laziness."

"Personally, due to the bus pass I walk much less."

"If I did not have a bus pass, I would walk to school every day."

"Since I live on campus, I often bus (instead of walk) from one class to another because I have the bus pass. If I did not have a bus pass, I would walk to all my classes since I have no additional use for a bus pass as I live on campus."

"... access to a bus pass will actually encourage students to walk less because they can take the bus for what is perceived as free due to the fact that bus passes are included in tuition."

"I think it reduces our physical activity level because many people are so accustomed to using it that even if they live a 10-15 minute walk to school they still catch the bus."

"I take the bus when I'm too lazy to walk. It means that I get less physical activity."

"It decreases the amount of walking done, so ultimately it decreases physical activity."

"It's probably the case that I would bike to school more often if I didn't have a cheap (and mandatory) bus pass included in my fees. As it stands, I sometimes bike to school during the warmer months, but more often take the bus."

Note. This table contains the most relevant quotations that reflect this theme; UWO = University of Western Ontario. 


\section{The discounted bus pass does not influence university students' physical activity}

levels. The minority of respondents expressed that the discounted bus pass does not influence their physical activity levels. Several students articulated that public transit is only a mode of transportation and they participate in physical activity in other settings such as the gym. As such, some students did not perceive that owning a discounted bus pass had any influence on their physical activity levels. Supporting quotations that express this theme are presented in Table 9. 
Table 9

Quotations Supporting the Theme "The Discounted Bus Pass Does Not Influence University Students' Physical Activity Levels”

"The amount of physical activity I do walking to the bus stop does not make a difference in my activity levels as I play varsity soccer and play every day, and get my work out there."

"I don't believe that having a bus pass affects physical activity to a high degree... If I were to drive, bike, bus or walk, I'd still use the gym the same amount."

"I would walk the same to the car as the bus because the parking lots at western are far from places on main campus."

"Rather than using my bus pass, I find it more convenient to walk everywhere. Since I don't have a car, the presence of transit won't make me walk more."

"I choose to be active in my life because I want to be healthy. The use of public transit, in no way, affects my decision to be healthy."

"I use London's public transit very frequently, but this does not stop my daily physical activity. I get that done separately at other times of [the] day."

"I find that having a bus pass has no influence on my physical activity. It almost seems counter productive to take a bus to a gym to work out, when walking there can act as my cardio work out."

"Overall, I do not think the bus system influences my physical activity because I enjoy walking to campus over taking the bus."

"Having a bus pass in no way influences my daily activity levels. I only use the bus to get to locations that would take me 30 or more minutes to walk to or if I am expecting to be bringing home many items that may be hard to carry."

Note. This table contains the most relevant quotations that reflect this theme. 


\section{Chapter 5: Discussion}

The purpose of this study was three-fold; to assess the relationship between full-time undergraduate Western University students': (a) perceptions of having a discounted bus pass and transit-related physical activity; (b) perceptions of having a discounted bus pass and weekly physical activity levels; and (c) transit-related physical activity and weekly physical activity levels. It was hypothesized that more positive perceptions of the discounted bus pass among Western undergraduate students' would be correlated with higher physical activity levels; this was in fact the case with regard to higher transit-related physical activity. However, since there were no statistically significant relationships reported between students' perceptions of the discounted bus pass and their weekly physical activity levels nor students' transit-related physical activity and their weekly physical activity levels, the results of this study only partially supported the initial hypotheses.

The major findings from this study illustrated that students who were provided with discounted transit passes may have increased their physical activity levels during their daily commutes. As described in the qualitative results (i.e., short answer responses), some participants in this study had mentioned that they were uncertain of whether the Western University Bus Pass was indeed beneficial for enhancing their physical activity levels because they may use their discounted bus passes to commute by transit for short distances. However, the majority of participants who completed the PT-PASS noted that they rarely used their discounted bus pass to ride the bus for short distances. This finding is particularly interesting because it contradicts previous findings, in which researchers have indicated that students who are provided with discounted or subsidized transit passes may have missed opportunities for physical activity because they will use public transit for short distances (Edwards et al., 2013; Jones et al., 2012). 
Similar to previous findings (Jones et al, 2012; Shannon et al., 2006; Villanueva et al., 2008), the majority of students perceived that their commutes by public transit were a way to accumulate more physical activity than their trips made by personal vehicles. Consequently, undergraduate students who struggle with maintaining adequate physical activity levels and meeting physical activity guidelines might benefit from receiving a discounted transit pass. In service of enhancing students' physical activity levels, post-secondary institutions should strive to develop and maintain a discounted universal transit pass program.

Several factors may have influenced students' perceptions of the discounted bus pass and its influence on their physical activity levels. For instance, some students described that they have preferences for other modes of active transportation, such as walking or biking, which may have affected their perceptions of the Western University Bus Pass on their physical activity levels (i.e., those who preferred to walk or bike perceived that the discounted bus pass had no influence on their physical activity levels). Also, several students explained that they did not perceive transit-related physical activities (e.g., walking to the bus stop, running to catch the bus, etc.) as being beneficial to their overall health. It is possible that highly active students (e.g., varsity athletes with high weekly physical activity levels) may have felt that small increases in their physical activity levels achieved via transit-related physical activities were irrelevant to them. As exemplified in the findings, some students felt that they were more active if they walked to the gym and/or complete their exercise at the gym. However, several students mentioned that the only way they can get to the gym during the winter months is by using their Western University Bus Pass, and as such, their discounted bus pass encouraged them to go the gym to be active. Further, the majority of students reported that they did not need to make any transfers while commuting by bus. This may have also affected students' perceptions of the 
discounted bus pass and its influence on their physical activity levels because transit users who make transfers during their commute may experience more opportunities for physical activity (i.e., walking to the next bus stop) compared to those who preferred direct routes that require no transfers (Morency et al., 2011; Wasifi et al., 2013). Thus, students' perceptions of the discounted bus pass and how they chose to use it had a major impact on whether they perceived any influences on their physical activity levels.

As described by Brown et al. (2001) and Shannon et al. (2006), there are many benefits of providing students with unlimited access to public transit through a subsidized or discounted transit pass program (e.g., reduced on-campus parking demands, reduced traffic congestion, reduced cost of attending school, increased mobility, and additional opportunities for physical activity). That said, it is important to consider the barriers that may prevent students from deciding to use public transit. The majority of Western undergraduate students who completed the online survey were in favour of the discounted bus pass program but perceived that there were several barriers to public transit that affected their overall perception of the Western University Bus Pass. Some examples of noted barriers to transit were that the city buses were not a reliable service and it was not convenient to travel by public transit when they had a lot to carry. Such obstacles may result in students choosing not to use public transit services. Individuals with access to personal vehicles may instead opt to drive personal vehicles instead, which as a result, may lead to increased traffic congestion on campuses (Eluru, Chakour, \& ElGeneidy, 2012; Zhou, 2012). It has been suggested for public transit agencies to provide dependable services (i.e., buses that run on schedule) and to reduce unexpected increases in travel time among transit users (Broome, Nalder, Worrall, \& Boldy, 2010). Brown et al. (2001) suggested that reliable transit services may be important for university students who usually walk 
or bike, but may prefer to use public transportation when travelling at night or during bad weather conditions. In their responses, Western undergraduate students confirmed that they would rely on transit more often during the Winter season and during periods of heavy rainfall. In order to reduce barriers to public transit, it is important that transit users, such as university students, be provided with reliable and comfortable public transit services that will meet their lifestyle needs and demands (Broome et al., 2010).

Although this study contributes to the ongoing research about the potential physical activity-related benefits of universal transit programs and public transit, it is still unclear whether there are significant physical activity-related benefits for different cohorts. Researchers suggested that public transit usage for adults is a form of active commuting/active transportation because it involves walking to transit stops and this may help increase daily step counts and physical activity levels for transit users (MacDonald et al., 2010; Morency et al., 2011; Villanueva et al., 2008; Wasfi, et al., 2013). Also, public transit has been considered an active mode of transportation for older adults, which has clear potentials for social- and health-related benefits for this population (Coroni-Cronberg, Millett, Laverty, \& Webb, 2012; Green, Jones, \& Roberts, 2014). In a recent study, Ermagun and Samimi (2015) have recommended that transit trips to school made by children and youths be perceived as partially active because they include walking trips to transit stations and stops. However, many researchers still differentiate public transit as a passive mode of transportation despite the report that it may promote increased participation in physical activity through walking (McDonald, 2007; Pabayo, Gauvin, \& Barnett, 2011; Reynolds, Winters, Ries, \& Gouge, 2010; Yang et al., 2014). As such, it is salient to further understand individuals' perceptions of public transit programs (e.g., universal transit programs, discounted bus pass programs, etc.) and their influence on physical activity levels. 
Although the primary significant findings from this study support that public transit, in particular, city buses, is an active mode of transportation for university students, partial findings from this study, for example the non-significant results between weekly physical activity levels and transit-related physical activity and students' perceptions of the discounted bus pass and their weekly physical activity levels, may preclude public transit as an active mode of transportation. However, the key findings of this study supported that public transit should be considered an active mode of transportation rather than passive or non-active because of the potential benefits it may have to promote active behaviours via access to recreational facilities (e.g., the school gym, yoga studios, etc.) and additional opportunities of physical activity during daily commutes for young adults. It is suggested that further research in this area is needed to develop definitive recommendations for bus pass ownership and public transit use for all.

Some researchers described that male university students tend to perform more physical activity than female students (Deng et al., 2011; Irwin, 2004). Similar to previous findings, this study also found that male participants had higher weekly physical activity levels than female participants. However, there were no statistically significant differences between males' and females' scores in sections two and three of the PT-PASS (i.e., no sex differences for perception of bus pass and transit-related physical activity scores). These results indicated that male and female university students perceived and utilized their discounted bus pass in similar ways. And although the majority of the sample consisted of female students, most respondents reported that they felt safe to use public transit in their neighbourhood and at night. This is an interesting finding because safety, especially at night, was speculated to be a major concern among female transit users. It is recommended that more research is needed to confirm these findings and to 
determine whether there are any potential differences regarding transit-related factors among university students.

The majority of respondents who completed the online survey were undergraduate students under the age of 24 years. Although the analyses did not include a comparison of agerelated differences, it would be interesting to see if older Canadian adults with discounted bus passes would have also gained physical activity-related benefits, such was the case among older adults in the United Kingdom (Coroni-Cronberg et al., 2012; Green et al., 2014). Different modes of active transportation provide adults of all ages the opportunity to engage in 'incidental physical activity', which may have unintended health-related benefits. Further research is needed to develop a clearer understanding of whether providing Canadian adults of various ages with discounted or subsidized transit passes will enhance their physical activity levels.

\section{Limitations and Future Directions}

The following limitations of this study should be considered. The first limitation of this study was that only an online survey was used as a data collection tool and participants were required to have access to a computer/device with an internet connection in order to complete it. This may have prevented access for students who wanted to complete the survey but did not have regular access to a computer/device with internet. An online survey (via SurveyMonkey®) was considered an acceptable data collection method and has been utilized in previous health-related studies at Western University (e.g., Ng \& Irwin, 2013; Pearson, Irwin, \& Morrow, 2013). Because data collection occurred within a limited time frame (approximately 11 weeks, from the end of August 2014 to the beginning of November 2014), it was decided that a convenience sample would be sufficient for the current study and a paper survey was considered a possible option if there was an insufficient response rate to the online survey. Given that multiple 
recruitment methods to invite Western undergraduate students to complete the online survey were employed, investigators considered the response rates and sample size to be sufficient for the analyses. As a result, a paper survey was not utilized in this study, which may have reduced the number of students who may have chosen to participate.

Another potential limitation was self-selection bias, which could have occurred due to participants' interest in the topics that were investigated (i.e., individuals who had greater interests in physical activity or the Western University Bus Pass might have been more likely to participate in the online survey than those with little to no interest in the topics). Moreover, social desirability bias was also a potential limitation because students may have overestimated their levels of physical activity and/or perhaps chose a different response due to the nature of the questions being asked. Additionally, the findings from this study have limited generalizability because the target population was young adults who were enrolled as full-time students at a Canadian university; as such, these findings may not be applicable and/or generalizable to other populations that may benefit from owning a discounted bus pass (e.g., teenagers and older adults, as described by Coroni-Cronberg et al., 2012; Edwards et al., 2013; Green et al., 2014; and Jones et al., 2012). In concert with the previous limitation, the majority of the students who participated in the online survey were Caucasian females from either the Faculty of Sciences or Faculty of Health Sciences (Table 1).

Other limitations included the absence of a 'gold standard' tool and objective measures as well as the utilization of Pearson bivariate correlations as part of the the analyses. Given that there was no available survey/questionnaire to measure the variables investigated in this study, a survey (i.e., the PT-PASS) was developed by the current research team to measure students' perceptions of the discounted bus pass and their transit-related physical activity. As a result, only 
face validity was established before the survey was used. Also, it is assumed that the selfreported data (from the online survey) within this study (e.g., measuring weekly physical activity levels using the IPAQ-SF) are less reliable than objective measures (e.g., measuring weekly physical activity levels using pedometers or accelerometers). The investigators decided to only use an online survey for this study because it was more cost efficient and appropriate for the sample size. Further, Pearson bivariate correlations are used to investigate potential relationships between variables but cannot provide suggestions for possible causation, which limits the potential strength of the findings.

Lastly, there were several uncontrollable factors that were related to the city buses and the Western University Bus Pass. Investigators could not implement a discounted bus pass program for a post-secondary institution due to financial constraints. The Western University Bus Pass is a well-established universal transit program that presents investigators with a unique opportunity to study the potential benefits and/or limitations for physical activity within a Canadian setting. Furthermore, because the City of London only has a single mode of public transit (i.e., the LTC only operates city buses), this may have limited the findings to be generalizable for other urban locations that include multiple modes of public transit (e.g., trains, subway, light rails, etc.). Thus, findings from this study may have suggested a weaker effect size because it was previously reported that adults who travel by multiple modes of public transportation (e.g., buses and trains), and make several transfers, may have additional opportunities for physical activity (Morency et al., 2011; Wasifi et al., 2013).

The decline in physical activity levels among university students has been reported in previous studies (Keating et al., 2005; Kwan et al., 2012). Findings from this study can potentially be utilized in future work to identify ways to increase bus pass ownership for 
university students in service of enhancing their physical activity levels. Future research should focus on whether increasing bus pass ownership within university institutions will influence students' physical activity levels. Additionally, researchers should determine whether the possession of a discounted bus pass would result in increased physical activity levels among graduate students, faculty members, and employees of postsecondary institutions. It is recommended that future researchers include comparison and control groups to establish more powerful statistical findings and the potential to develop strong causational relationships to support their findings. Lastly, researchers should include objective physical activity measures (e.g., pedometers or accelerometers) to obtain more reliable results within future studies.

\section{Conclusions}

The results from this study provide important insights for innovative Canadian campusbased programs looking to enhance university students' physical activity levels. Although the preliminary findings of this work suggest the discounted bus pass is potentially beneficial, additional research is warranted to help establish a clearer understanding of whether discounted bus pass ownership is beneficial to promoting significant increases in university students' physical activity levels. 


\section{References}

Barata, E., Cruz, L., \& Ferreira, J. (2011). Parking at the UC campus: Problems and solutions. Cities, 28(5), 406-413. doi: 10.1016/j.cities.2011.04.001

Bates, B.L. (1992). The effect of demands for honesty on the efficacy of the Carleton SkillsTraining Program. International Journal of Clinical and Experimental Hypnosis, 40(2), 88-102. doi: 10.1080/00207149208409650

Behrens, T., Dinger, M., Heesch, K., \& Sisson, S. (2005). College students' understanding of moderate physical activity: A qualitative study. American Journal of Health Studies, 20(3/4), 129-134. Retrieved from http://www.va-ajhs.com/20-3/index.aspx

Besser, L. M., \& Dannenberg, A. L. (2005). Walking to public transit: Steps to help meet physical activity recommendations. American Journal of Preventive Medicine, 29(4), 273-280. doi: 10.1016/j.amepre.2005.06.010

Broome, K., Nalder, E., Worrall, L., \& Boldy, D. (2010). Age-friendly buses? A comparison of reported barriers and facilitators to bus use for younger and older adults. Australasian Journal on Ageing, 29(1), 33-38. doi: 10.1111/j.1741-6612.2009.00382.x

Brown, J., Hess, D., \& Shoup, D. (2001). Unlimited access. Transportation 28(3), 233-267. doi: 10.1023/A:1010307801490

Brown, J., Hess, D., \& Shoup, D. (2003). Fare-free public transit at universities: An evaluation. Journal of Planning Education and Research, 23(1), 69-82. doi: $10.1177 / 0739456 \times 03255430$

Burke, S. M., Carron, A. V., \& Eys, M. A. (2006). Physical activity context: Preferences of university students. Psychology of Sport and Exercise, 7(1), 1-13. doi: 10.1016/j.psychsport.2005.03.002 
Canadian Society for Exercise Physiology. (2012). Canadian physical activity guidelines and Canadian sedentary behaviour guidelines. Ottawa, ON: Canadian Society for Exercise Physiology. Retrieved from http://www.csep.ca/english/view.asp?x=804

Canadian University Survey Consortium. (2011). Canadian university survey consortium: 2011 undergraduate university student survey. Ottawa, ON: Prairies Research Associate. Retrieved from http://www.cuscccreu.ca/publications/CUSC_2011_UG_MasterReport.pdf

Canadian Urban Transit Association. (2004). U-Pass toolkit: The complete guide to universal transit pass programs at Canadian colleges and universities. Toronto: ON: Noxon Associates Limited. Retrieved from http://www.bctransit.com/marketing/resources/ toolkits/U-PassToolkit.pdf

Caspersen, C. J., Powell, K. E., \& Christenson, G. M. (1985). Physical activity, exercise, and physical fitness: Definitions and distinctions for health-related research. Public Health Reports, 100(2), 126-131. Retrieved from http://www.ncbi.nlm.nih.gov/pmc/issues/129807/

Cholewa, S., \& Irwin, J. D. (2008). Project IMPACT: Brief report on a pilot programme promoting physical activity among university students. Journal of Health Psychology, 13(8), 1207-1212. doi: 10.1177/1359105308095979

Cohen, J. (1988). Statistical power analysis for the behavioral sciences (2nd ed.). Hillsdale, NJ: Lawrence Erlbaum Associates.

Coronini-Cronberg, S., Millett, C., Laverty, A., \& Webb, E. (2012). The impact of a free older persons' bus pass on active travel and regular walking in England. American Journal of Public Health, 102(11), 2141-2148. doi: 10.2105/ajph.2012 
Craig, C. L., Marshall, A. L., Sjostrom, M., Bauman, A. E., Booth, M. L., Ainsworth, B. E., , . Oja, P. (2003). International Physical Activity Questionnaire: 12-country reliability and validity. Medicine and Science in Sports and Exercise, 35(8), 1381-1395. doi:

10.1249/01.MSS.0000078924.61453.FB

Deng, X., Castelli, D., Castro-Pinero, J., \& Hongwei, G. (2011). University students meeting the recommended standards of physical activity and body mass index. International Council for Health, Physical Education, Recreation, Sport, and Dance Journal of Research, 6(1), 20-26. Retrieved from http://www.ichpersd.org/i/publications/vol_6.pdf

Dorsey, B. (2005). Mass transit trends and the role of unlimited access in transportation demand management. Journal of Transport Geography, 13(3), 235-246. doi:

10.1016/j.jtrangeo.2004.07.004

Drolet, M. (2005). Participation in post-secondary education in Canada: Has the role changed over the 1990s? Ottawa, ON: Statistics Canada.

Edwards, P., Steinbach, R., Green, J., Petticrew, M., Goodman, A., Jones, A., ... Wilkinson, P. (2013). Health impacts of free bus travel for young people: Evaluation of a natural experiment in London. Journal of Epidemiology and Community Health, 67(8), 641-647. doi: $10.1136 /$ jech2012-202156

Edwards, R. D. (2008). Public transit, obesity, and medical costs: Assessing the magnitudes. Preventive Medicine, 46(1), 14-21. doi: 10.1016/j.ypmed.2007.10.004

Eluru, N., Chakour, V., \& El-Geneidy, A. (2012). Travel mode choice and transit route choice behavior in Montreal: Insights from McGill University members commute patterns. Public Transport, 4(2), 129-149. doi: 10.1007/s12469-012-0056-2

Ermagun, A., \& Samimi, A. (2015). Promoting active transportation modes in school trips. 
Transport Policy, 37, 203-211. doi: 10.1016/j.tranpol.2014.10.013

Fountaine, C., Liguori, G., Mozumdar, A., \& Schuna, J. (2011). Physical activity and screen time sedentary behaviors in college students. International Journal of Exercise Science, 4(2), 102-112. Retrieved from http://digitalcommons.wku.edu/ijes/vol4/iss2/3/

Freudenberg, N., Manzo, L., Mongiello, L., Jones, H., Boeri, N., \& Lamberson, P. (2013).

Promoting the health of young adults in urban public universities: A case study from city university of New York. Journal of American College Health, 61(7), 422-430. doi: $10.1080 / 07448481.2013 .823972$

Green, J., Jones, A., \& Roberts, H. (2014). More than A to B: The role of free bus travel for the mobility and wellbeing of older citizens in London. Ageing and Society, 34(3), 472-494. doi: 10.1017/S0144686X12001110

Guba, E.G., \& Lincoln, Y.S. (1989). Fourth generation evaluation. London, England: Sage Publications.

Haskell, W. L., Lee, I. M., Pate, R. R., Powell, K. E., Blair, S. N., Franklin, B. A., . . Bauman, A. (2007). Physical activity and public health: Updated recommendation for adults from the American College of Sports Medicine and the American Heart Association. Medicine and Science in Sports and Exercise, 39(8), 1423-1434. doi:

10.1249/mss.0b013e3180616b27

Huesman, R., Brown, A., Lee, G., Kellogg, J., \& Radcliffe, P. (2009). Gym bags and mortarboards: Is use of campus recreation facilities related to student success? National Association of Student Personnel Administrators Journal, 46(1), 50-71. doi: $10.2202 / 1949-6605.5005$

International Physical Activity Questionnaire. (2002). International Physical Activity 
Questionnaire short last 7 days self-administered format. Retrieved from https://sites.google.com/site/theipaq/questionnaire_links

International Physical Activity Questionnaire. (2005). Guidelines for data processing and analysis of the International Physical Activity Questionnaire (IPAQ) - Short and long forms. Retrieved from https://sites.google.com/site/theipaq/scoring-protocol

Irwin, J. D. (2004). Prevalence of university students' sufficient physical activity: A systematic review. Perceptual and Motor Skills, 98, 927-943. doi: 10.2466/pms.98.3.927-943

Irwin, J. D. (2007). The prevalence of physical activity maintenance in a sample of university students: A longitudinal study. Journal of American College Health 56(1), 37-41. doi: 10.3200/JACH.56.1.37-42

Jones, A., Steinbach, R., Roberts, H., Goodman, A., \& Green, J. (2012). Rethinking passive transport: Bus fare exemptions and young people's wellbeing. Health and Place, 18(3), 605-612. doi: 10.1016/j.healthplace.2012.01.003

Katz, A., Davis, P., \& Findlay, S. S. (2002). Ask and ye shall plan: A health needs assessment of a university population. Canadian Journal of Public Health, 93(1), 63-66. Retrieved from http://journal.cpha.ca/index.php/cjph/article/view/274/274

Keating, X.D., Castelli, D., \& Ayers, S. (2013). Association of weekly strength exercise frequency and academic performance among students at a large university in the United States. Journal of Strength and Conditioning Research, 27(7), 1988-1993. doi: 10.1519/JSC.0b013e318276bb4c

Keating, X.D., Guan, J., Pinero, J.C., \& Bridges, D.M. (2005). A meta-analysis of college students' physical activity behaviors. Journal of American College Health, 54(2), 116125. doi: 10.3200/JACH.54.2.116-126 
Kwan, M., Faulkner, G., \& Bray, S. (2013). Evaluation of active transition, a website-delivered physical activity intervention for university students: Pilot study. Journal of Medical Internet Research, 2(1), 1-9. doi: 10.2196/resprot.2099

Kwan, M. Y., Cairney, J., Faulkner, G. E., \& Pullenayegum, E. E. (2012). Physical activity and other health-risk behaviors during the transition into early adulthood: A longitudinal cohort study. American Journal of Preventive Medicine, 42(1), 14-20. doi: 10.1016/j.amepre.2011.08.026

Lachapelle, U., \& Frank, L. (2009). Transit and health: Mode of transport, employer-sponsored public transit pass programs, and physical activity. Journal of Public Health Policy, 30, 73-94. doi: $10.1057 /$ jphp.2008.52

Laska, M. N., Pelletier, J. E., Larson, N. I., \& Story, M. (2012). Interventions for weight gain prevention during the transition to young adulthood: A review of the literature. Journal of Adolescent Health, 50(4), 324-333. doi: 10.1016/j.jadohealth.2012.01.016

London Transit Commission. (2006). London Transit Commission transportation demand management study: Long-term transit growth strategy - Final technical report (Dillon Consulting Limited No. 05-5149). Retrieved from http://www.london.ca/residents/RoadsTransportation/Transportation-Planning/Documents/LTC_long_term_technical_report_ July2006.pdf

London Transit Commission. (2013). Fares. Retrieved from http://www.Itconline.ca/Fares.htm MacDonald, J. M., Stokes, R. J., Cohen, D. A., Kofner, A., \& Ridgeway, G. K. (2010). The effect of light rail transit on body mass index and physical activity. American Journal of Preventive Medicine, 39(2), 105-112. doi: 10.1016/j.amepre.2010.03.016

Maglione, J. L., \& Hayman, L. L. (2009). Correlates of physical activity in low income college 
students. Research in Nursing and Health, 32(6), 634-646. doi: 10.1002/nur.20353

Marzoughi, R. (2011). Teen travel in the Greater Toronto Area: A descriptive analysis of trends from 1986 to 2006 and the policy implications. Transport Policy, 18(4), 623-630. doi: 10.1016/j.tranpol.2011.03.004

McDonald, N. C. (2007). Active transportation to school: Trends among U.S. schoolchildren, 1969-2001. American Journal of Preventive Medicine, 32(6), 509-516. doi: 10.1016/j.amepre.2007.02.022

McKenzie, J. F., Neiger, B. L., \& Thackeray, R. (2013). Planning, implementing and evaluating health promotion programs: A primer (6th ed.). Toronto, ON: Pearson.

Morency, C., Trepanier, M., \& Demers, M. (2011). Walking to transit: An unexpected source of physical activity. Transport Policy, 18(6), 800-806. doi: 10.1016/j.tranpol.2011.03.010

Ng, V., \& Irwin, J. D. (2013). Prescriptive medicine: The importance of preparing Canadian medical students to counsel patients toward physical activity. Journal of Physical Activity and Health, 10(6), 889-899. Retrieved from http://journals.humankinetics.com/AcuCustom/Sitename/Documents/DocumentItem/14_ Ng_JPAH_20110385_ej.pdf

Pabayo, R., Gauvin, L., \& Barnett, T. A. (2011). Longitudinal changes in active transportation to school in Canadian youth aged 6 through 16 years. Pediatrics, 128(2), 404-413. doi: 10.1542/peds.2010-1612

Paez, A., \& Whalen, K. (2010). Enjoyment of commute: A comparison of different transportation modes. Transportation Research Part A: Policy and Practice, 44(7), 537549. doi: 10.1016/j.tra.2010.04.003

Pate, R. R., Pratt, M., Blairs, S. N., Haskell, W. L., Macera, C. A., Bouchard, C., . . Buchner, D. 
(1995). Physical activity and public health: A recommendation from the Centers for Disease Control and Prevention and the American College of Sports Medicine. Journal of American Medical Association, 273(5), 402-407. doi:

10.1001/jama.1995.03520290054029

Patton, M. Q. (2002). Qualitative research and evaluation methods (3rd ed.). London, UK: Sage.

Pearson, E. S., Irwin, J. D., \& Morrow, D. (2013). The CHANGE Program: Methodology for comparing interactive Co-Active coaching with a prescriptive lifestyle treatment for obesity. International Journal of Evidence Based Coaching and Mentoring, 11(1), 69-84. Retrieved from http://ijebcm.brookes.ac.uk/documents/vol11issue1-paper-05.pdf

Reynolds, C. C. O., Winters, M., Ries, F. J., Gouge, B. (2010). Active transportation in urban areas: Exploring health benefits and risks. Vancouver, BC: National Collaborating Centre for Environmental Health.

Rissel, C., Curac, N., Greenaway, M., \& Bauman, A. (2012). Physical activity associated with public transport use: A review and modelling of potential benefits. International Journal of Environmental Research and Public Health, 9(7), 2454-2478. doi:

10.3390/ijerph9072454

Romaguera, D., Tauler, P., Bennasar, M., Pericas, J., Moreno, C., Martinez, S., \& Aguilo, A. (2011). Determinants and patterns of physical activity practice among Spanish university students. Journal of Sports Sciences, 29(9), 989-997. doi:

$10.1080 / 02640414.2011 .578149$

Shannon, T., Giles-Corti, B., Pikora, T., Bulsara, M., Shilton, T., \& Bull, F. (2006). Active commuting in a university setting: Assessing commuting habits and potential for modal change. Transport Policy, 13(3), 240-253. doi: 10.1016/j.tranpol.2005.11.002 
Statistics Canada. (2010). Trends in the age composition of college and university students and graduates. Retrieved from http://www.statcan.gc.ca/pub/81-004-x/2010005/article/ 11386-eng.htm\#a

Statistics Canada. (2012). Census Profile, 2011 Census: London, Ontario. Retrieved from http://www12.statcan.gc.ca/census-recensement/2011/dp-pd/prof/details/ page.cfm?Lang $=\mathrm{E} \&$ Geo $1=\mathrm{CSD} \&$ Code $1=3539036 \& \mathrm{Geo} 2=\mathrm{CD} \& \mathrm{Code} 2=3539 \&$ Data $=\mathrm{Co}$ unt $\&$ SearchText=london $\&$ SearchType $=$ Begins $\&$ SearchPR $=01 \& B 1=$ All $\&$ Custom $=\& T A$ $\mathrm{BID}=1$

Stewart-Brown, S., Evans, J., Patterson, J., Petersen, S., Doll, H., Balding, J., \& Regis, D. (2000). The health of students in institutes of higher education: An important and neglected public health problem? Journal of Public Health Medicine, 22(4), 492-499. doi: 10.1093/pubmed/22.4.492

SurveyMonkey Inc., https://www.surveymonkey.com (last visited April 29, 2014)

Toronto Transit Commission. (2010). Post-secondary student metropass eligibility (Report No. 3.77.54). Retrieved from http://www.ttc.ca/About_the_TTC/Commission_reports_and _information/Commission_meetings/2010/Dec_15_2010/Reports/Post_Secondary_Stude. pdf

Transport Canada. (2004). Universal transit passes in Canada (Publication No. TP14270E). Retrieved from http://publications.gc.ca/collections/collection_2012/tc/T41-1-25-eng.pdf Transport Canada. (2008). Transportation demand management at Canada's post-secondary institutions (Publication No. TP14714E). Retrieved from http://publications.gc.ca/ collections/collection_2012/tc/T41-1-66-eng.pdf

Tremblay, M. S., Warburton, D. E., Janssen, I., Paterson, D. H., Latimer, A. E., Rhodes, R. E., 
... Duggan, M. (2011). New Canadian physical activity guidelines. Applied Physiology, Nutrition, and Metabolism, 36(1), 36-46. doi: 10.1139/H11-009

Tucker, P., \& Irwin, J. D. (2006). Feasibility of a campus-based "buddy system" to promote physical activity: Canadian students' perspectives. Journal of Physical Activity and Health, 3(3), 323-334. Retrieved from http://journals.humankinetics.com/AcuCustom/ Sitename/Documents/DocumentItem/6015.pdf

Tucker, P., \& Irwin, J. D. (2011). University students' satisfaction with, interest in improving, and receptivity to attending programs aimed at health and well-being. Health Promotion Practice, 12(3), 388-395. doi: 10.1177/1524839908330814

Tudor-Locke, C., \& Bassett, D. R. Jr. (2004). How Many Steps/Day Are Enough? Preliminary Pedometer Indices for Public Health. Sports Medicine, 34(1), 1-8. doi: $10.2165 / 00007256-200434010-00001$

Tully, M., \& Cupples, M. (2011). UNISTEP (University Students Exercise and Physical Activity) study: A pilot study of the effects of accumulating 10,000 steps on health and fitness among university students. Journal of Physical Activity and Health 8(5), 663-667. Retrieved from http://journals.humankinetics.com/AcuCustom/Sitename/Documents/ DocumentItem/08_tully_JPAH_20090241.pdf

University Students' Council. (2010). Bus Pass Policy. Retrieved from http://www.usc.uwo.ca/buspass/Bus_Pass_Policy.pdf

Villanueva, K., Giles-Corti, B., \& McCormack, G. (2008). Achieving 10,000 steps: A comparison of public transport users and drivers in a university setting. Preventive Medicine, 47(3), 338-341. doi: 10.1016/j.ypmed.2008.03.005

Warburton, D. E., Nicol, C. W. , \& Bredin, S. S. (2006). Health benefits of physical activity: The 
evidence. Canadian Medical Association Journal, 174(6), 801-809. Retrieved from http://www.cmaj.ca/content/174/6/801.full.pdf+html

Wasfi, R. A., Ross, N. A., \& El-Geneidy, A. M. (2013). Achieving recommended daily physical activity levels through commuting by public transportation: Unpacking individual and contextual influences. Health and Place, 23, 18-25. doi:

10.1016/j.healthplace.2013.04.006

Wener, R., \& Evans, G. (2007). A morning stroll: Levels of physical activity in car and mass transit commuting. Environment and Behavior, 39(1), 62-74. doi:

$10.1177 / 0013916506295571$

Western University. (2013a). Ancillary fee schedule for 2013-2014. Retrieved from http://www.registrar.uwo.ca/student_finances/fees_refunds/pdfs $\% 20$ fee $\% 20$ schedule $\% 20$ /Ancillary\%20Fees\%202013-2014.pdf

Western University. (2013b). Five-year enrolment comparison. Retrieved from http://www.ipb.uwo.ca/documents/2013_five_year_enrolment_comparison.pdf

Western University. (2014). Viewbook 2014. Retrieved from http://welcome.uwo.ca/PDFs/VB_2014_Web.pdf

World Health Organization. (2010). Global recommendations on physical activity for health. Retrieved from http://whqlibdoc.who.int/publications/2010/9789241599979_eng.pdf

Yang, X., Telama, R., Hirvensalo, M., Tammelin, T., Viikari, J. S., \& Raitakari, O. T. (2014). Active commuting from youth to adulthood and as a predictor of physical activity in early midlife: The young Finns study. Preventive Medicine, 59, 5-11. doi: 10.1016/j.ypmed.2013.10.019 
Zhou, J. (2012). Sustainable commute in a car-dominant city: Factors affecting alternative mode choices among university students. Transportation Research Part A: Policy and Practice, 46(7), 1013-1029. doi: 10.1016/j.tra.2012.04.001 


\section{Appendix A: Ethics Approval Notice}

\section{Western} Research

\section{Western University Health Science Research Ethics Board NMREB Delegated Initial Approval Notice}

Principal Investigator: Dr. Jennifer Irwin

Department \& Institution: Health Sciences, Western University

NMREB File Number: 105491

Study Title: University students' perceptions of the relationship between bus pass ownership and physical activity levels

Sponsor:

NMREB Initial Approval Date: August 22, 2014

NMREB Expiry Date: January 31, 2015

Documents Approved and/or Received for Information:

\begin{tabular}{|c|c|c|}
\hline Document Name & Comments & $\begin{array}{l}\text { Version } \\
\text { Date }\end{array}$ \\
\hline Instruments & $\begin{array}{l}\text { The online survey is divided into three parts (Perception of Transit-Related } \\
\text { Physical Activity Student Survey, International Physical Activity } \\
\text { Questionnaire - Short Form, and Demographic Information). }\end{array}$ & $2014 / 06 / 23$ \\
\hline Recruitment Items & Recruitment flyer with detachable tabs. & $2014 / 07 / 18$ \\
\hline Recruitment Items & The email script that will be sent to course instructors. & $2014 / 07 / 18$ \\
\hline $\begin{array}{l}\text { Revised Letter of } \\
\text { Information \& } \\
\text { Consent }\end{array}$ & The clean copy of the revised Letter of Information. & $2014 / 07 / 18$ \\
\hline $\begin{array}{l}\text { Revised Western } \\
\text { University Protocol }\end{array}$ & The clean copy of the revised Western Protocol. & $2014 / 07 / 18$ \\
\hline
\end{tabular}

The Western University Non-Medical Research Ethics Board (NMREB) has reviewed and approved the above named study, as of the HSREB Initial Approval Date noted above.

NMREB approval for this study remains valid until the NMREB Expiry Date noted above, conditional to timely submission and acceptance of HSREB Continuing Ethics Review.

The Western University NMREB operates in compliance with the Tri-Council Policy Statement Ethical Conduct for Research Involving Humans (TCPS2), the Ontario Personal Health Information Protection Act (PHIPA, 2004), and the applicable laws and regulations of Ontario.

Members of the NMREB who are named as Investigators in research studies do not participate in discussions related to, nor vote on such studies when they are presented to the REB.

The NMREB is registered with the U.S. Department of Health \& Human Services under the IRB registration number IRB 00000941.

\begin{tabular}{l} 
Ethics Officer, on behalf of Riley Hinson, NMREB Chair \\
$\qquad$ Erika Basile \\
\hline Ethics Officer to Contact for Further Information \\
\hline Grace Kelly
\end{tabular}


Appendix B: Recruitment Flyer

\section{University Students' Perceptions of the Relationship} between Bus Pass Ownership and Physical Activity Levels

\section{Participants needed for an online survey! PROVIDE YOUR OPINIONS ABOUT THE BUS PASS!}

Researchers from the Faculty of Health Sciences are conducting a study to assess Western undergraduate students' perceptions of how having a discounted bus pass might influence their physical activity levels.

\section{Who can participate?}

* Full-time Western undergraduate students who are eligible for the Western University Bus Pass are invited to participate in an anonymous online survey.

\section{How to participate?}

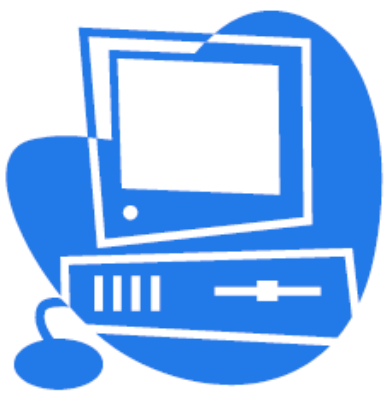

* The following link will lead you to the online survey: http://surveymonkey.com/s/buspassandphysicalactivity

* The online survey will take approximately 10 minutes to complete and the link to the survey will stay open until November $7^{\text {th }}, 2014$.

\section{Need more information?}

* For further information about participating in this study, you are welcome to contact Dr. Jennifer D. Irwin (*email*) or Hieu Ly (*email*).

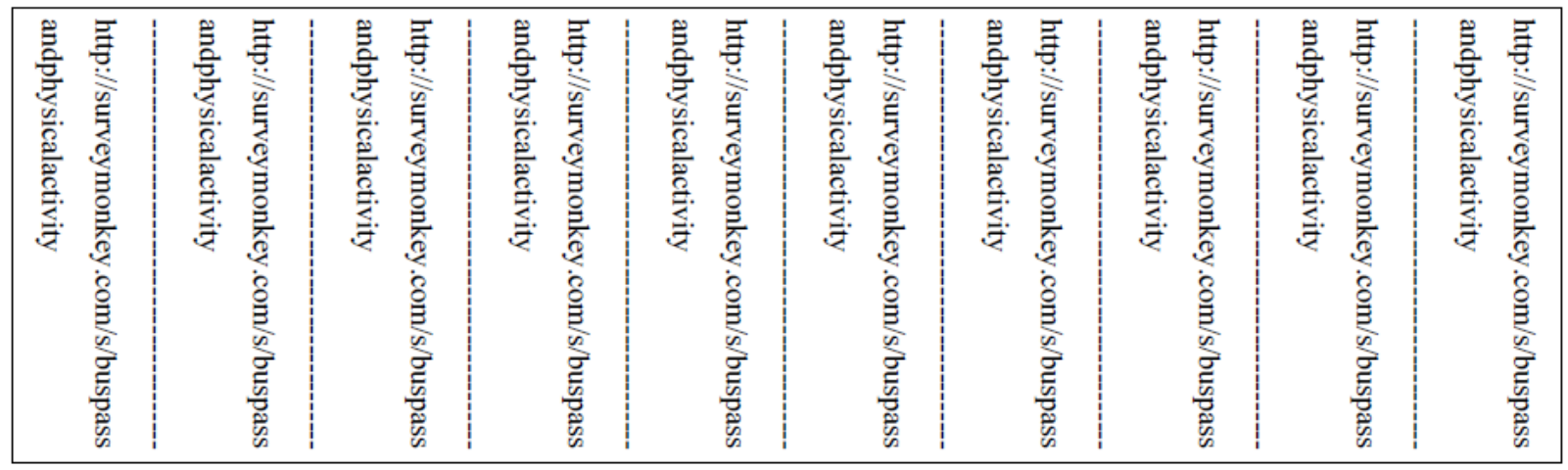


Appendix C: Invitation Email to Course Instructors

Subject Line: Survey on Student Bus Pass and Physical Activity

Hello,

Researchers from the Faculty of Health Sciences are conducting a study to assess Western undergraduate students' perceptions of how having a discounted bus pass might influence their physical activity levels. In this study, full-time Western undergraduate students who are eligible for the Western University Bus Pass will be asked to participate in an online survey that will assess their perceptions of how having a discounted bus pass might influence their physical activity levels.

We are contacting you today to request that the following recruitment statement below be posted on your OWL course website to invite students to participate in an anonymous online survey. The online survey will take approximately 5 - 10 minutes to complete and will gather valuable information about Western students' perceptions of how having the Western University Bus Pass might influence physical activity levels and choices.

"Dear student,

Researchers from the Faculty of Health Sciences are conducting a study to assess Western undergraduate students' perceptions of how having a discounted bus pass might influence their physical activity levels. If you are interested in taking part in this study, please begin by reviewing the Letter of Information on the first page of the survey. The link to the survey will stay open until November $7^{\text {th }}, 2014$. If you wish to participate in this study, the following link will lead you to the online survey: http://surveymonkey.com/s/buspassandphysicalactivity

Thank you in advance for your time. For further information about this study, you are welcome to contact Dr. Jennifer D. Irwin (*email*) or Hieu Ly (*email*).”

Thank you for considering our request. We would be happy to share the survey with you beforehand, and share the results with you after the study is completed. If you have any questions and/or require further information about this study, you are welcome to contact Dr. Jennifer D. Irwin $(*$ email*) or Hieu Ly (*email*).

Best regards,

Hieu Ly, BSc. (Hons.), MSc. student in Health Promotion

Faculty of Health Sciences

Western University

London, Ontario CANADA N6G 1H1 
Appendix D: Letter of Information

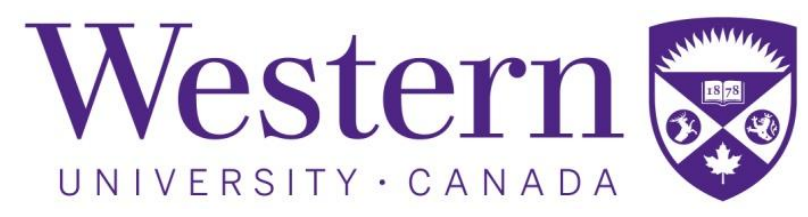

\section{University Students' Perceptions of the Relationship between Bus Pass Ownership and Physical Activity Levels}

\section{Investigators:}

Jennifer D. Irwin, PhD, Faculty of Health Sciences, Western University

Hieu Ly, BSc, Faculty of Health Sciences, Western University

\section{Purpose of the Study:}

The purpose of the current study is to assess Western University undergraduate students' perceptions of how having a discounted bus pass might influence their physical activity levels. Full-time undergraduate students eligible for the Western University Bus Pass will be recruited to complete an anonymous online survey for this study.

\section{Voluntary Participation:}

Participation in this study is voluntary. If you choose to participate, you are able to leave any question unanswered, should you choose to do so, and still complete the remainder of the questionnaire. You may withdraw from the study at anytime without any penalty. Your participation in this study will have no impact on evaluations of you of any kind, academically or otherwise.

\section{If You Decide to Participate:}

If you decide to participate in this study, you will be asked to complete a 10 minute online survey through SurveyMonkey®. By accessing and completing the survey, you are providing implied consent to participate. Please note that the survey is located on Survey Monkey, which is hosted on United States' servers and as such, is subject to the United States Patriot Act. All information collected is confidential.

\section{Confidentiality:}

No names or identifiers will be collected within the study and information gathered will only be used for publishing or presentations purposes. Data collected from this study will only be accessible by the investigators and will be safeguarded on password protected devices, which will be destroyed after 5 years.

\section{Cost and Compensation:}

There is no cost to participate in this study. No compensation will be given for participation in this study. 


\section{Risks \& Benefits:}

There are no known risks for participating in this study. Your participation in this study will provide researchers with valuable information about Western students' perceptions of how having the Western University Bus Pass might influence physical activity levels and choices.

\section{Feedback from the Study:}

If you wish to receive the results from this study, please send an e-mail to Hieu Ly at *email*.

If you have any questions and/or require further information about participating in this study, you are welcome to contact Dr. Jennifer D. Irwin (*email*) or Hieu Ly (*email*). If you have any questions about your rights as a research participant, please contact Western's Office of Research Ethics at *email* or (xxx) xxx-xxxx. 
Appendix E: Reminder Email to Course Instructors

Subject Line: Survey on Student Bus Pass and Physical Activity

Hello,

Earlier this month, I sent you an email requesting your assistance in recruiting undergraduate students to complete a short online survey for my MSc thesis project. I appreciate that September is a very busy month and my email may have been one of many you received and therefore, I am sending it again now to ask that if you haven't already posted the survey link on your OWL site and are willing to do so, please copy and post the following recruitment statement below. The online survey will take approximately 5 - 10 minutes to complete and will gather valuable information about Western students' perceptions of how having the Western University Bus Pass might influence physical activity levels and choices. Also, I am wondering if I or a research assistant could make a quick announcement at the start of one of your classes to bring the study to your students' attention. If making a class announcement doesn't work for you, having it posted on your OWL site only would also be much appreciated. Thank you for your consideration.

"Dear student,

Researchers from the Faculty of Health Sciences are conducting a study to assess Western undergraduate students' perceptions of how having a discounted bus pass might influence their physical activity levels. If you are interested in taking part in this study, please begin by reviewing the Letter of Information on the first page of the survey. The link to the survey will stay open until November $7^{\text {th }}, 2014$. If you wish to participate in this study, the following link will lead you to the online survey: http://surveymonkey.com/s/buspassandphysicalactivity

Thank you in advance for your time. For further information about this study, you are welcome to contact Dr. Jennifer D. Irwin (*email*) or Hieu Ly (*email*).”

Thank you again for considering this request. If you have any questions and/or require further information about this study, you are welcome to contact Dr. Jennifer D. Irwin (*email*) or Hieu Ly (*email*).

Best regards, Hieu Ly, BSc. (Hons.), MSc. student in Health Promotion Faculty of Health Sciences

Western University London, Ontario CANADA N6G 1H1 
Appendix F: The Online Survey

\section{Part A: Perception of Transit-Related Physical Activity Student Survey (PT-PASS)}

\section{Objective}

The Perception of Transit-Related Physical Activity Student Survey (PT-PASS) was developed to assess Western University undergraduate students' perceptions of how having a discounted bus pass might influence their physical activity levels.

\section{Instructions}

The PT-PASS is a self-administered survey. The complete online survey will take approximately 10 minutes to complete. Your decision to complete the survey constitutes consent. Your participation in this survey is completely voluntary and will not have an impact on your grades. You may skip any of the questions or withdraw from the study at any time. There are no right or wrong answers, please only select the option that best reflects your honest views, experiences, or opinions. Thank you for taking the time to complete this survey.

\section{Section 1: Modes of Transportation}

This first section is about students' preferences for different modes of transportation. Please select the most appropriate answer relevant for you, personally, for each response.

1. Generally, I often use the following method to commute (e.g., to school, to work, etc.):

$\square$ Walk $\quad \square$ Bike $\quad \square$ Bus $\quad \square$ Car $\quad \square$ Other, please specify:

2. I have access to a bicycle that I can use:

$\square$ Yes $\quad \square$ No

3. I have access to a vehicle that I can use (e.g., car, truck, etc.):

$\square$ Yes $\quad \square$ No

4. I have a parking permit at Western University:

$\square$ Yes $\quad \square$ No

5. With regard to access to public transit services:

$\square$ I have a Western University Bus Pass.

$\square$ I purchase a monthly bus pass from the London Transit Commission (LTC).

$\square$ I use individual fares (e.g., bus tickets, cash payments, etc.).

6. I usually make transfers (changing buses) during a transit trip:

$\square 0 \quad \square 1 \quad \square 2 \quad \square$ 3 or more 
7. With regard to paratransit services (i.e., special transit services for individuals with an impairment/disability):

$\square$ I require paratransit services for an impairment/disability.

$\square$ I do not require paratransit services for an impairment/disability.

$\square$ I do not have an impairment/disability and do not require paratransit services.

\section{Section 2: Bus Pass and Transit Trips}

This second section includes questions about various facilitators or barriers that might influence your decision about using the Western University Bus Pass and public transit. Please select the most appropriate answer relevant for you, personally, for each response.

8. Public transit trips are enjoyable transitions between home and school/work.

$\begin{array}{lllc}\text { Strongly } & \text { Disagree } & \text { Neither Agree } & \text { Agree } \\ \text { Disagree } & \text { nor Disagree } & \text { Strongly } \\ & & \text { Agree }\end{array}$

9. I am comfortable being around strangers when I travel by public transit.

$\begin{array}{llll}\text { Strongly } & \text { Disagree } & \text { Neither Agree } & \text { Strongly } \\ \text { Disagree } & \text { nor Disagree } & \text { Agree }\end{array}$

10. I travel by public transit because my friends/colleagues use this mode of transportation.

$\begin{array}{llll}\text { Strongly } & \text { Disagree } & \text { Neither Agree } & \text { Strongly } \\ \text { Disagree } & & \text { nor Disagree } & \text { Agree }\end{array}$

11. It is convenient to travel by public transit when I have a lot to carry (e.g., gym bags, grocery bags, etc.).

$\begin{array}{llll}\text { Strongly } & \text { Disagree } & \text { Neither Agree } & \text { Strongly } \\ \text { Disagree } & & \text { nor Disagree } & \text { Agree }\end{array}$

12. I travel by public transit when it is cold or raining outside.

$\begin{array}{llll}\text { Strongly } & \text { Disagree } & \text { Neither Agree } & \text { Strongly } \\ \text { Disagree } & \text { nor Disagree } & \text { Agree }\end{array}$

13. The public transit in my area is usually comfortable, clean, and well-maintained.

$\begin{array}{lllc}\text { Strongly } & \text { Disagree } & \text { Neither Agree } & \text { Agree } \\ \text { Disagree } & \text { nor Disagree } & \text { Strongly } \\ & & \text { Agree }\end{array}$

14. I feel safe to use public transit at night.

Strongly

Disagree

Disagree

Neither Agree

nor Disagree
Strongly Agree 
15. The public transit services in my area are reliable (e.g., sufficient services, never late, available every day of the week, etc.).

$\begin{array}{llll}\text { Strongly } & \text { Disagree } & \text { Neither Agree } & \text { Strongly } \\ \text { Disagree } & \text { nor Disagree } & \text { Agree }\end{array}$

16. I feel safe when walking to the transit stop in my neighbourhood.

$\begin{array}{llll}\text { Strongly } & \text { Disagree } & \text { Neither Agree } & \text { Strongly } \\ \text { Disagree } & & \text { nor Disagree } & \text { Agree }\end{array}$

17. I often use public transit to travel to places I can be physically active (e.g., gym, fitness studios, etc.).

\begin{tabular}{|c|c|}
\hline $\begin{array}{l}\text { Strongly } \\
\text { Disagree }\end{array}$ & Disagree \\
\hline
\end{tabular}

18. I often use my Western University Bus Pass.

$\begin{array}{llll}\text { Strongly } & \text { Disagree } & \text { Neither Agree } & \text { Strongly } \\ \text { Disagree } & & \text { nor Disagree } & \text { Agree }\end{array}$

19. I use public transit because of my Western University Bus Pass.

$\begin{array}{llll}\text { Strongly } & \text { Disagree } & \text { Neither Agree } & \text { Strongly } \\ \text { Disagree } & \text { nor Disagree } & \text { Agree }\end{array}$

20. I am in favour of Western University Bus Pass program for undergraduate students.

$\begin{array}{llll}\text { Strongly } & \text { Disagree } & \text { Neither Agree } & \text { Strongly } \\ \text { Disagree } & \text { nor Disagree } & \text { Agree }\end{array}$

21. I use my Western University Bus Pass to save money.

$\begin{array}{llll}\text { Strongly } & \text { Disagree } & \text { Neither Agree } & \text { Strongly } \\ \text { Disagree } & \text { nor Disagree } & \text { Agree }\end{array}$

22. I can travel anywhere in the city using my Western University Bus Pass.

\begin{tabular}{|c|}
\hline $\begin{array}{l}\text { Strongly } \\
\text { Disagree }\end{array}$ \\
\hline
\end{tabular}

23. I travel by car less often because I have my Western University Bus Pass.

Strongly
Disagree

Disagree
Neither Agree nor Disagree
Strongly Agree 
24. I have additional opportunities to travel because my Western University Bus Pass provides unlimited access to public transit.

$\begin{array}{llll}\text { Strongly } & \text { Disagree } & \text { Neither Agree } & \text { Strongly } \\ \text { Disagree } & \text { nor Disagree } & \text { Agree }\end{array}$

25. I often travel to appointments (e.g., job interviews, medical assessments, etc.) and complete errands (e.g., shopping for groceries, returning library books, etc.) using my Western University Bus Pass.

\begin{tabular}{|c|}
\hline $\begin{array}{l}\text { Strongly } \\
\text { Disagree }\end{array}$ \\
\hline
\end{tabular}

26. I have the opportunity to participate in leisure activities because of my Western University Bus Pass.
Strongly
Disagree
Neither Agree
nor Disagree
Agree
Strongly
Agree

27. I use my Western University Bus Pass to travel by public transit because it is more environmentally friendly than travelling by car.

$\begin{array}{llll}\text { Strongly } & \text { Disagree } & \text { Neither Agree } & \text { Strongly } \\ \text { Disagree } & & \text { nor Disagree } & \text { Agree }\end{array}$

\section{Section 3: Transit Behaviours}

This last section is about students' typical transit-related behaviours that might influence their physical activity levels. Please select the most appropriate answer relevant for you, personally, for each response (excluding \#45).

28. Walking to the bus stop helps make me more active.

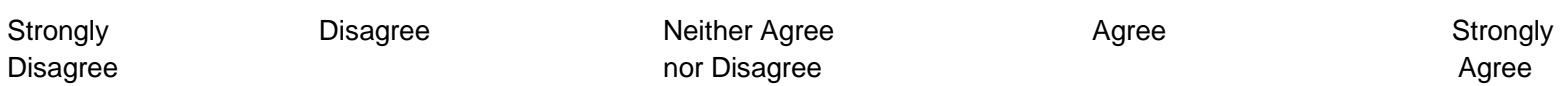

29. I spend more time walking when I use public transit than when I drive.

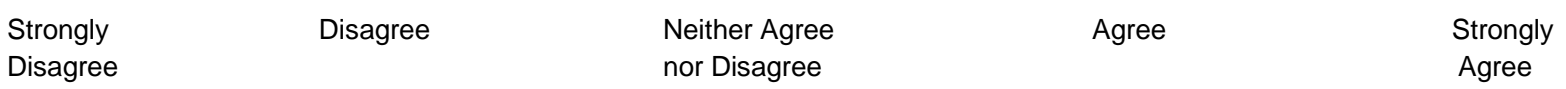

30. I rarely use my Western University Bus Pass to ride the bus for short distances (e.g., one or two stops).

Strongly Disagree
Disagree nor Disagree
Agree

Strongly Agree 
31. If I am early for my bus, I will walk to a different bus stop (i.e., one that is farther away).

\begin{tabular}{|c|}
\hline $\begin{array}{l}\text { Strongly } \\
\text { Disagree }\end{array}$ \\
\hline
\end{tabular}

32. When I miss the bus, I will walk to the next bus stop on my route.

$\begin{array}{llll}\text { Strongly } & \text { Disagree } & \text { Neither Agree } & \text { Agree } \\ \text { Disagree } & & \text { nor Disagree } & \text { Strongly } \\ \text { Agree }\end{array}$

33. I enjoy walking to/from the bus stop.

$\begin{array}{llll}\text { Strongly } & \text { Disagree } & \text { Neither Agree } & \text { Strongly } \\ \text { Disagree } & \text { nor Disagree } & \text { Agree }\end{array}$

34. When I transfer from one bus to another, I often have to run to catch my next bus.

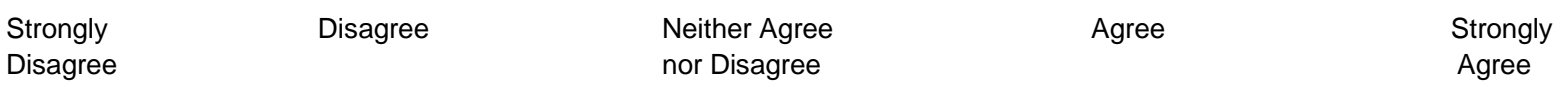

35. I often walk around the bus stop area while I wait for the bus.

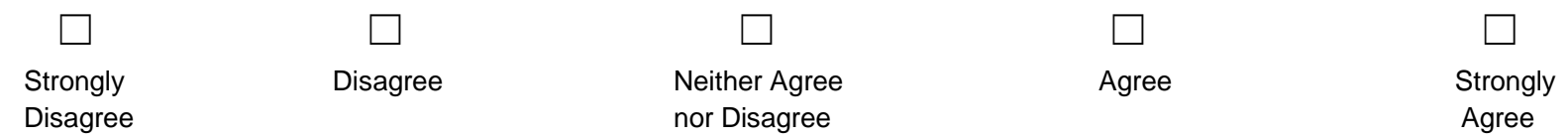

36. When I use my Western University Bus Pass, I often accumulate 30 minutes of walking during my transit trip(s).

\begin{tabular}{|c|c|c|c|}
\hline $\begin{array}{l}\text { Strongly } \\
\text { Disagree }\end{array}$ & Disagree & $\begin{array}{l}\text { Neither Agree } \\
\text { nor Disagree }\end{array}$ & Agree \\
\hline
\end{tabular}

37. I rarely sit for long periods when I use the bus.

$\begin{array}{llll}\text { Strongly } & \text { Disagree } & \text { Neither Agree } & \text { Strongly } \\ \text { Disagree } & \text { nor Disagree } & \text { Agree }\end{array}$

38. I often have/choose to stand in the bus.
$\square$
Strongly
Disagree
Disagree
Neither Agree
nor Disagree
Strongly Agree

39. My Western University Bus Pass often helps increase my overall physical activity levels.

Agree 
40. I usually walk quickly to catch the bus.

$\begin{array}{lll}\text { Strongly } & \text { Disagree } & \text { Neither Agree } \\ \text { Disagree } & & \text { nor Disagree }\end{array}$

nor Disagree

Agree

Strongly

Agree

41. I often bike to a bus stop.

Strongly

Disagree

Neither Agree

nor Disagree

Agree

Strongly

Disagree

42. I rarely get driven to a bus stop.

Strongly
Disagree

Disagree

Neither Agree

nor Disagree

Agree

Strongly

Agree

43. I walk more often because of my Western University Bus Pass.

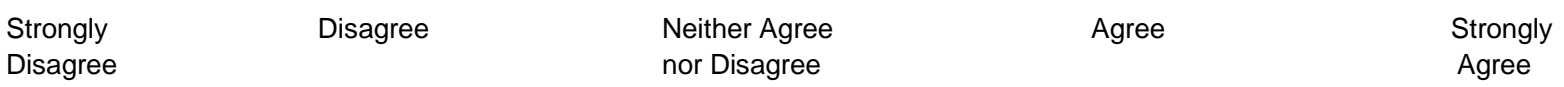

44. Using public transit is a way to accumulate physical activity during my daily commutes.

\begin{tabular}{|c|}
\hline $\begin{array}{l}\text { Strongly } \\
\text { Disagree }\end{array}$ \\
\hline
\end{tabular}

45. The purpose of this survey is to assess Western undergraduate students' perceptions of how having a discounted bus pass might influence their physical activity levels. Please use the space below to provide any comments you might have regarding this topic.

\section{Part B: International Physical Activity Questionnaire (IPAQ)}

We are interested in finding out about the kinds of physical activities that people do as part of their everyday lives. The questions will ask you about the time you spent being physically active in the last 7 days. Please answer each question even if you do not consider yourself to be an active person. Please think about the activities you do at work, as part of your house and yard work, to get from place to place, and in your spare time for recreation, exercise or sport.

Think about all the vigorous activities that you did in the last 7 days. Vigorous physical activities refer to activities that take hard physical effort and make you breathe much harder than normal. Think only about those physical activities that you did for at least 10 minutes at a time. 
1. During the last 7 days, on how many days did you do vigorous physical activities like heavy lifting, digging, aerobics, or fast bicycling?

\section{days per week}

$\square$ No vigorous physical activities

$\longrightarrow$ Skip to question 3

2. How much time did you usually spend doing vigorous physical activities on one of those days?

hours per day minutes per day

$\square$ Don't know/Not sure

Think about all the moderate activities that you did in the last 7 days. Moderate activities refer to activities that take moderate physical effort and make you breathe somewhat harder than normal. Think only about those physical activities that you did for at least 10 minutes at a time.

3. During the last 7 days, on how many days did you do moderate physical activities like carrying light loads, bicycling at a regular pace, or doubles tennis? Do not include walking.

\section{days per week
$\square$ No moderate physical activities $\longrightarrow$ Skip to question 5}

4. How much time did you usually spend doing moderate physical activities on one of those days?

hours per day

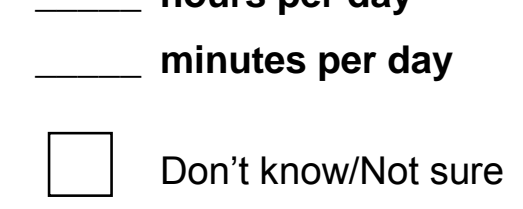

Think about the time you spent walking in the last $\mathbf{7}$ days. This includes at work and at home, walking to travel from place to place, and any other walking that you have done solely for recreation, sport, exercise, or leisure.

5. During the last $\mathbf{7}$ days, on how many days did you walk for at least 10 minutes at a time?

days per week

$\square$ No walking $\longrightarrow$ Skip to question 7 
6. How much time did you usually spend walking on one of those days?

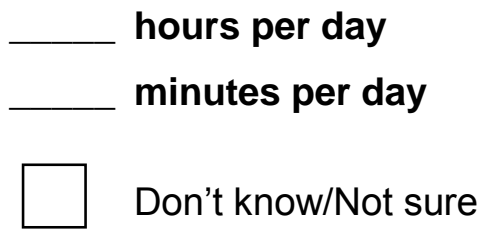

The last question is about the time you spent sitting on weekdays during the last 7 days. Include time spent at work, at home, while doing course work and during leisure time. This may include time spent sitting at a desk, visiting friends, reading, or sitting or lying down to watch television.

7. During the last $\mathbf{7}$ days, how much time did you spend sitting on a week day?

hours per day minutes per day

$\square$ Don't know/Not sure

\section{Part C: Demographic Information}

This section contains questions about your background and personal information. Please select the most appropriate answer relevant for you, personally, for each response.

1. Sex:

$\square$ Male

$\square$ Female

$\square$ Prefer not to disclose

$\square$ Other, please specify:

2. Age:

$\square 19$ years and under

$\square 20$-24 years

$\square 25-29$ years

$\square$ 30-34 years

3. Ethnicity:

$\square$ Aboriginal

$\square$ African Heritage

$\square$ Caucasian

$\square$ East Asian

\author{
$\square$ 35-39 years \\ $\square 40-44$ years \\ $\square$ 45-49 years \\ $\square 50$ years and over
}

$\square$ Hispanic

$\square$ Middle Eastern

$\square$ South Asian

$\square$ Other, please specify: 
4. Current student's enrollment status at Western University:

$\square$ Part-time

$\square$ Full-time

5. Program of registration:

$\square$ Faculty of Arts and Humanities

$\square$ Faculty of Education

$\square$ Faculty of Law

$\square$ Faculty of Engineering

$\square$ Faculty of Music

$\square$ Faculty of Health Sciences

$\square$ Faculty of Science

$\square$ Faculty of Information and Media Studies

$\square$ Faculty of Social Science

$\square$ Other, please specify:

6. Year of academic enrollment:

$\square$ First

$\square$ Second

$\square$ Third

$\square$ Fourth

$\square$ Fifth

$\square$ Other, please specify:

7. Employment status:

$\square$ Not employed $\quad \square$ Part-time $\quad \square$ Full-time

8. With regards to your place of residence:

$\square$ I live in London, Ontario during the Fall and Winter semesters

$\square$ I live in London, Ontario during the Fall, Winter, and Summer semesters

$\square$ I do not live in London, Ontario

9. My living arrangement is:

$\square$ On campus (i.e., residence) $\square$ Off-campus with roommates

$\square$ Off-campus by myself $\quad \square$ Off-campus with family or relatives

\section{This is the end of the survey, thank you for participating.}


Appendix G: International Physical Activity Questionnaire Scoring Protocol (Short Forms)

\section{International Physical Activity Questionnaire Scoring Protocol (Short Forms)}

\section{Continuous Score}

Expressed as MET-min per week: MET level $x$ minutes of activity/day $x$ days per week

\section{Sample Calculation}

\section{MET levels}

Walking = 3.3 METs

Moderate Intensity $=4.0$ METs

Vigorous Intensity $=8.0$ METs
MET-minutes/week for $30 \mathrm{~min} /$ day, 5 days

$3.3 * 30 * 5=495 \mathrm{MET}-$ minutes/week

$4.0 * 30 * 5=600 \mathrm{MET}$-minutes/week

$8.0 * 30 * 5=1,200 \mathrm{MET}$-minutes/week

$\overline{\text { TOTAL } \quad=2,295 \mathrm{MET}-\text { minutes/week }}$

Total MET-minutes $/$ week $=$ Walk $($ METs*min*days $)+$ Mod $($ METs*min*days $)+$ Vig (METs*min*days)

\section{Categorical Score- three levels of physical activity are proposed}

\section{Low}

- No activity is reported OR

- $\quad$ Some activity is reported but not enough to meet Categories 2 or 3.

\section{2. $\quad$ Moderate}

Either of the following 3 criteria

- 3 or more days of vigorous activity of at least 20 minutes per day OR

- 5 or more days of moderate-intensity activity and/or walking of at least 30 minutes per day OR

- 5 or more days of any combination of walking, moderate-intensity or vigorous intensity activities achieving a minimum of at least 600 MET-minutes/week.

\section{High}

Any one of the following 2 criteria

- Vigorous-intensity activity on at least 3 days and accumulating at least 1500 MET-minutes/week OR

- 7 or more days of any combination of walking, moderate- or vigorous-intensity activities accumulating at least 3000 MET-minutes/week 


\section{CURRICULUM VITAE}

\section{PERSONAL INFORMATION:}

Name: Hieu Ly

\section{EDUCATION:}

$2013-2015$

$2011-2013$

$2008-2013$

3. HONOURS AND AWARDS

$2013-2015$

\section{EMPLOYMENT HISTORY}

$2010-2012$

Summer 2010

\section{TEACHING EXPERIENCE}

Fall 2014
Western University, London Ontario, Canada M.Sc. Student, Health and Rehabilitation Sciences Thesis Title: University Students' Perceptions of the Relationship between Bus Pass Ownership and Physical Activity Levels

Seneca College, Toronto, Ontario, Canada

York-Seneca Rehabilitation Services Certificate

York University, Toronto, Ontario, Canada Honours B.Sc., Kinesiology and Psychology Thesis Title: Levels of Physical Exercise Self-Efficacy and Physical Activity among University Students
Research Assistant

Department of Kinesiology and Health Science, York University, Toronto, Ontario, Canada

Research Assistant

Department of Psychology, York University, Toronto, Ontario, Canada
Teaching Assistant

Department of Health and Rehabilitation Sciences, Western University, London, Ontario, Canada

Health Sciences 2250A: Health Promotion in Canada 
Fall 2013

$2011-2012$

$2010-2011$

Spring 2009
Teaching Assistant

Department of Health and Rehabilitation Sciences, Western University, London, Ontario, Canada

Physical Therapy 9535A: Physical Therapy in

Rehabilitation Settings II

Support Staff and Guest Lecturer

Sir John A. MacDonald Collegiate Institute, Toronto,

Ontario, Canada

Tutor for Undergraduate Psychology Student Association York University, Toronto, Ontario, Canada

Teaching Assistant

Morrish Public School, Toronto, Ontario, Canada

\section{PUBLICATIONS}

Ly, H. (2014). Barriers to Healthcare Services among Recent Immigrants in Canadian Cities. Health Science Inquiry, 5(1), 37-38.

\section{PRESENATIONS}

Ly, H., \& Irwin, J.D. University students' perceptions of the relationship between bus pass ownership and physical activity levels. Health and Rehabilitation Sciences Graduate Research Conference. London, ON, February 4, 2015. Abstract and Oral Presentation.

Ly, H., \& Irwin, J.D. Bus pass and physical activity: University students' perceptions. Robert Macmillan Graduate Research in Education Symposium. London, ON, April 10, 2014. Abstract and Poster Presentation.

Ly, H., \& Irwin, J.D. Bus pass and physical activity: University students' perceptions. Faculty of Health Sciences' Research Day. London, ON, March 25, 2014. Abstract and Poster Presentation.

Ly, H., \& Irwin, J.D. Bus pass and physical activity: University students' perceptions. Western Research Forum. London, ON, March 17-19, 2014. Abstract and Oral Presentation.

\section{ACADEMIC CONFERENCES}

October 3, 2014

August 27, 2014
Exercise is Medicine on Campus Annual Symposium, Western University

Fall Perspectives on Teaching Conference, Western University 
May 14, 2014

Spring Perspectives on Teaching Conference, Western University

\section{PROFESSIONAL ASSOCIATION MEMBERSHIP}

2014 - Present

2014 - Present

2013 - Present
International Union for Health Promotion and Education

Sedentary Behaviour Research Network

Canadian Obesity Network 